\title{
Affinity resins containing enzymatically resistant mRNA cap analogs-a new tool for the analysis of cap-binding proteins
}

\author{
SYLWIA ANNA SZCZEPANIAK, ${ }^{1,2,3}$ JOANNA ZUBEREK, ${ }^{1}$ EDWARD DARZYNKIEWICZ, ${ }^{1}$ JOANNA KUFEL, ${ }^{2,4}$ \\ and JACEK JEMIELITY'1,4 \\ ${ }^{1}$ Division of Biophysics, Institute of Experimental Physics, Faculty of Physics, University of Warsaw, 02-089 Warsaw, Poland \\ ${ }^{2}$ Institute of Genetics and Biotechnology, Faculty of Biology, University of Warsaw, 02-106 Warsaw, Poland \\ ${ }^{3}$ College of Inter-Faculty Individual Studies in Mathematics and Natural Sciences, University of Warsaw, 02-089 Warsaw, Poland
}

\begin{abstract}
Cap-binding proteins have been routinely isolated using $\mathrm{m}^{7}$ GTP-Sepharose; however, this resin is inefficient for proteins such as DcpS (scavenger decapping enzyme), which interacts not only with the 7-methylguanosine, but also with the second cap base. In addition, DcpS purification may be hindered by the reduced resin capacity due to the ability of DcpS to hydrolyze $\mathrm{m}^{7} \mathrm{GTP}$. Here, we report the synthesis of new affinity resins, $m^{7} \mathrm{GpCH}_{2} p p$ - and $\mathrm{m}^{7} \mathrm{GpCH}_{2}$ ppA-Sepharoses, with attached cap analogs resistant to hydrolysis by DcpS. Biochemical tests showed that these matrices, as well as a hydrolyzable $\mathrm{m}^{7} \mathrm{GpppA}^{-S e p h a r o s e}$, bind recombinant mouse elF4 $\mathrm{E}^{(28-217)}$ specifically and at high capacity. In addition, purification of cap-binding proteins from yeast extracts confirmed the presence of all expected cap-binding proteins, including DcpS in the case of $\mathbf{m}^{7} \mathrm{GpCH}_{2} \mathrm{pp}$ - and $\mathrm{m}^{7} \mathrm{GpCH}_{2} \mathrm{ppA}$-Sepharoses. In contrast, binding studies in vitro demonstrated that recombinant human DcpS efficiently bound only $\mathrm{m}^{7} \mathrm{GpCH}_{2}$ ppA-Sepharose. Our data prove the applicability of these novel resins, especially $\mathrm{m}^{7} \mathrm{GpCH}_{2} \mathrm{ppA}-\mathrm{Sepharose}$ in biochemical studies such as the isolation and identification of cap-binding proteins from different organisms.
\end{abstract}

Keywords: affinity chromatography; cap analogs; cap-binding proteins; decapping enzymes; DcpS

\section{INTRODUCTION}

Precursors of all RNA classes synthesized by eukaryotic RNA polymerase II (Pol II) are capped at their $5^{\prime}$ ends. The basic cap structure consists of the 7-methylguanosine moiety $\left(\mathrm{m}^{7} \mathrm{G}\right)$ connected to the first nucleoside of the nascent transcript by a $5^{\prime}-5^{\prime}$ triphosphate bridge, which is atypical for nucleic acids. The role of this structure is to protect RNA from $5^{\prime} \rightarrow 3^{\prime}$ exonucleases, which are not capable of hydrolyzing pyrophosphate bonds within the $5^{\prime}-5^{\prime}$ triphosphate bridge. Moreover, cap recognition by specific proteins is essential for several cellular processes, including pre-mRNA splicing, nucleocytoplasmic mRNA export and localization and, finally, translation initiation (Topisirovic et al. 2011). Similarly, the cap structure of snRNA in metazoa plays a role as its localization signal. The $\mathrm{m}^{7} \mathrm{G}$ cap of an

${ }^{4}$ Corresponding authors

E-mail jacekj@biogeo.uw.edu.pl

E-mail kufel@ibb.waw.pl

Article published online ahead of print. Article and publication date are at http://www.rnajournal.org/cgi/doi/10.1261/rna.032078.111.
snRNA precursor drives its export to the cytoplasm, whereas a hypermethylated TMG (trimethylguanosine) cap directs snRNP import to the nucleus (Matera et al. 2007).

There are two major cellular cap-binding complexes: the predominantly nuclear cap-binding complex (CBC) and mainly cytoplasmic eukaryotic initiation factor $4 \mathrm{~F}$ (eIF4F). $\mathrm{CBC}$ is a heterodimer composed of Cbp20, which directly binds the cap structure, and Cbp80, which supports this interaction (Izaurralde et al. 1994; Calero et al. 2002; Mazza et al. 2002a). CBC binds the $\mathrm{m}^{7} \mathrm{G}$ cap immediately following its synthesis and mediates its participation in premRNA processing and nucleocytoplasmic export (Flaherty et al. 1997; Lewis and Izaurralde 1997; Shen et al. 2000). In the cytoplasm, CBC is replaced by eIF4F during the initial round of translation due to the interaction of $\mathrm{Cbp} 80$ and the eIF4F subunit, eIF4G (McKendrick et al. 2001; BaronBenhamou et al. 2003). The cytoplasmic cap-binding protein, eIF4E, plays an essential role in cap-dependent translation initiation and is a crucial target of its regulation (for review, see von der Haar et al. 2004; Richter and Sonenberg 2005).

Cap hydrolysis by specific pyrophosphatases (decapping enzymes) plays a crucial role in mRNA decay, as the $5^{\prime} \rightarrow 3^{\prime}$ 
degradation pathway requires the hydrolysis of the pyrophosphate bond. On the other hand, the resulting free cap structure can affect the function of cap-binding complexes by sequestering them from their RNA substrates (Bail and Kiledjian 2008). To circumvent this, two types of decapping enzymes with different substrate specificity hydrolyze the cap structure (Liu and Kiledjian 2006). The Dcp1/Dcp2 complex degrades caps of long deadenylated mRNAs, making them accessible to $5^{\prime} \rightarrow 3^{\prime}$ exonucleases, while the scavenger decapping pyrophosphatase DcpS acts on the free cap and short-capped RNA molecules resulting from $3^{\prime} \rightarrow 5^{\prime} \mathrm{mRNA}$ degradation by the exosome (Liu et al. 2002). The specificity of the two decapping enzymes toward the cleavage site differs: Dcp1/Dcp2 cleaves between the $\alpha$ and $\beta$ phosphate groups, resulting in $\mathrm{m}^{7} \mathrm{GDP}$ and $\mathrm{pN}-\mathrm{RNA}$, whereas DcpS hydrolyzes the $\beta-\gamma$ pyrophosphate bond to release $\mathrm{m}^{7} \mathrm{GMP}$ and $\mathrm{pp}(\mathrm{Np})_{1-10}$.

As a key regulator of the free cap structure, and consequently of the pool of available cap-binding proteins, DcpS is considered an important general modulator of capdependent processes (Bail and Kiledjian 2008). For example, mammalian DcpS is important for efficient removal of the cap-proximal intron, a process depending on CBCmediated association of U1 snRNP to the $5^{\prime}$ splice site (Shen et al. 2008). DcpS depletion entails reduced first intron removal by sequestering $\mathrm{CBC}$ from the cap structure as a result of an imbalanced cap level. In turn, in Saccharomyces cerevisiae, the lack of DcpS, or its catalytic activity, decreases $5^{\prime} \rightarrow 3^{\prime}$ mRNA decay at the level of exonucleolytic degradation (Liu and Kiledjian 2005). It has been proposed that either the cap structure or the decapping product serve as a signaling molecule for downstream functions. Recently, $\mathrm{hDcpS}$ has been identified as a molecular target of C5quinazolines, which are potential therapeutics for spinal muscular atrophy (SMA) (Singh et al. 2008). Inhibition of DcpS by these drugs increases the expression of the SMN2 gene, which can complement the defective levels of the survival motor neuron (SMN) protein causing SMA. It has been proposed that the role of DcpS in buffering the active pool of cap-binding proteins is more general and serves as a regulatory feedback mechanism that links the final steps of mRNA decay to earlier events in mRNA biogenesis, namely, mRNA processing, export, and translation initiation (Bail and Kiledjian 2008).

Considering the high specificity of cap recognition, capbinding proteins can be purified by affinity chromatography using cap-modified resins. The first affinity matrices of this type that used the analogs of $\mathrm{m}^{7} \mathrm{GDP}$ immobilized by a modified ribose moiety have been used for isolation of eIF4E and associated translation factors, usually from partially fractionated cell lysates (Sonenberg et al. 1979; Altmann et al. 1985; Edery et al. 1988; Ptushkina et al. 1996). The most successful, and up to now the only widely applied approach, utilizes $\mathrm{m}^{7} \mathrm{GTP}$-Sepharose, which has been shown to specifically bind both cap-binding complexes (Webb et al. 1984).
It has been used for the purification and identification of eIF4E isoforms from different organisms using either endogenous protein extracts or recombinant proteins expressed in bacteria (Browning et al. 1987; Zapata et al. 1994; JankowskaAnyszka et al. 1998; Ruud et al. 1998; Ramirez et al. 2002). Although eIF4E has a much higher affinity for $\mathrm{m}^{7} \mathrm{GTP}$ Sepharose than other cap-binding proteins, this resin also permitted the identification of a cap-specific Nhm1 pyrophosphatase from Schizosaccharomyces pombe, which was found as a contaminant in the eIF4F preparation (Ptushkina et al. 1996; Salehi et al. 2002). Cap-analog affinity resins are also utilized for pull down assays and in vitro binding studies of cap-binding proteins (Mazza et al. 2002b; Kiriakidou et al. 2007; Nojima et al. 2007; Pabis et al. 2010). For example, some new dinucleotide cap analog-modified resins synthesized recently were shown to bind the Caenorhabditis elegans IFE-5 isoform with the capacity comparable to their mononucleotide counterparts (Jankowska-Anyszka and Piecyk 2011).

However, the applications described above are practical mainly for eIF4F or CBC, as the binding of specific pyrophosphatases, such as DcpS, to $\mathrm{m}^{7} \mathrm{GTP}-$ Sepharose is less efficient, particularly in the presence of the whole-cell extract, where proteins with higher affinities effectively compete out DcpS, thus obstructing its purification (Salehi et al. 2002). More importantly, DcpS can hydrolyze $\mathrm{m}^{7} \mathrm{GTP}$, which may significantly reduce resin capacity.

To synthesize an enzymatically stable affinity resin that can be applied for DcpS purification, we have used cap analogs modified with a methylenebisphosphonate moiety in the $\beta / \gamma$ position of the $5^{\prime}-5^{\prime}$ triphosphate bridge, which constitutes the DcpS cleavage site. Analogs of this type were shown to bind human DcpS specifically and to be resistant to hydrolysis by this protein (Kalek et al. 2006). To this end, two nonhydrolyzable cap analogs, mononucleotide $\mathrm{m}^{7} \mathrm{GpCH}_{2} \mathrm{pp}$ or dinucleotide $\mathrm{m}^{7} \mathrm{GpCH}_{2} \mathrm{ppA}$, were attached directly or via a 1,6-diaminohexane spacer arm, respectively, to the Sepharose. In addition, a hydrolyzable dinucleotide $\mathrm{m}^{7} \mathrm{GpppA}$-Sepharose was also synthesized to enhance the affinity of other cap-binding proteins. Binding studies with recombinant proteins and purification of cap-binding proteins from yeast extract showed that the binding capacity of novel affinity resins for known cap-binding proteins was similar to that of standard $\mathrm{m}^{7} \mathrm{GTP}-\mathrm{Sepharose}$, but only $\mathrm{m}^{7} \mathrm{GpCH}_{2} \mathrm{ppA}$-Sepharose efficiently bound recombinant or crude yeast extract-derived DcpS.

\section{RESULTS AND DISCUSSION}

\section{Chemical synthesis of new affinity resins}

We synthesized three novel affinity resins with attached cap analogs (Table 1): $\mathrm{m}^{7} \mathrm{GpCH}_{2} \mathrm{pp}$-Sepharose (2), $\mathrm{m}^{7}$ GpppA-Sepharose (3), and $\mathrm{m}^{7} \mathrm{GpCH}_{2} \mathrm{ppA}$-Sepharose (4). Enzymatically stable $\mathrm{m}^{7} \mathrm{GpCH}_{2} \mathrm{pp}$-Sepharose (2) and 
TABLE 1. Structures of $\mathrm{m}^{7}$ GTP-Sepharose and affinity resins synthesized in this study

\begin{tabular}{lllllc}
\hline & Compound/Sepharose & $\mathrm{X}$ & $\begin{array}{c}\mathrm{DS} \\
{\left[\mu \mathrm{mol} \times \mathrm{ml}^{-1}\right]}\end{array}$ \\
\hline & $\mathbf{1}$ & $\mathrm{m}^{7} \mathrm{GTP}-$ Sepharose & $\mathrm{O}$ & $0.042 \pm 0.010$ \\
\hline
\end{tabular}

the reaction medium were applied to obtain the desired product in a reasonable yield (66\% yield by HPLC). Another phenomenon of this reaction is its regioselectivity. There are two possible sites for the nucleophilic attack of $p$-nitrophenol on either the P2 or P3 phosphorus atom. In theory, attack on the P2 atom, leading to an undesirable byproduct, should be preferred with regard to the adjacent methylene group, which makes the P2 atom more electrophilic (Kalek et al. 2005b). Surpris$\mathrm{m}^{7} \mathrm{GpCH}_{2} \mathrm{ppA}$-Sepharose (4) are resistant to hydrolysis by DcpS due to methylene group substitution for pyrophosphate oxygen atom closest to the $\mathrm{m}^{7} \mathrm{G}$ moiety. These two resins, $\mathrm{m}^{7} \mathrm{GpppA}$ - and $\mathrm{m}^{7} \mathrm{GpCH}_{2} \mathrm{ppA}$-Sepharoses, are among the first examples of the affinity medium with dinucleotide cap analogs attached to the matrix.

The synthesis of $\mathrm{m}^{7} \mathrm{GpCH}_{2} \mathrm{pp}$-Sepharose (2) (Fig. 1A) was performed using the strategy described in Knorre et al. (1976) and Webb et al. (1984). $\mathrm{m}^{7} \mathrm{GpCH}_{2} \mathrm{pp}$ (8) was obtained using a methodology previously devised by our group (Kalek et al. 2005a, 2006). The bisphosphonate moiety was introduced into the nucleotide by direct phosphonylation of guanosine with methylenebis(phosphonic dichloride) in trimethyl phosphate as the solvent (Kalek et al. 2005b). The resultant $\mathrm{GpCH}_{2} \mathrm{p}$ (5) was coupled to another phosphate moiety using a two-step procedure. It involved activation of the nucleoside $5^{\prime}$-bisphosphonate with an imidazole exploiting the 2,2'-dithiodipyridine/triphenylphosphine activation system (Mukaiyama and Hashimoto 1972), followed by actual coupling of the obtained imidazole derivative (6) to bis(triethylammonium) phosphate in the presence of $\mathrm{ZnCl}_{2}$ (Kadokura et al. 1997; Stepinski et al. 2001; Jemielity et al. 2003; Kalek et al. 2006). Subsequent methylation of the intermediate 7 with $\mathrm{CH}_{3} \mathrm{I}$ produced the final cap analog (8). Prior to coupling to Sepharose, $\mathrm{m}^{7} \mathrm{GpCH} \mathrm{P}_{2} \mathrm{pp}$ (8) was converted into a $p$-aminophenyl $\gamma$-ester derivative (11), following the three-step procedure described in Knorre et al. (1976) and Webb et al. (1984). The first step, activation of 8 by converting it into its tri- $n$-octylammonium salt and its subsequent cyclization with DCC proceeded easily using the same conditions, but the third reaction, involving the nucleophilic attack of $p$-nitrophenol on the phosphate group, took place with much slower kinetics than in the case of $\mathrm{m}^{7}$ GTP. $\mathrm{m}^{7}$ GTP trimetaphosphate hydrolyzes almost immediately in aqueous solutions, but the presence of a methylene group within the triphosphate chain makes the cyclic trimetaphosphate-like intermediate (9) more stable under standard reaction conditions (Trowbridge et al. 1972), which allowed us to monitor the reaction progress using HPLC. The increased stability of intermediate 9 correlates well with its decreased reactivity; therefore, a prolonged incubation time combined with an increased concentration of TEA in ingly, only the required terminal $p$-nitrophenyl ester formation was observed, meaning that either the attack on P3 is favorable in this case, or the $\beta$-ester is labile and converts into the $\gamma$-ester $(\mathbf{1 0})$. The nitro group was subsequently reduced to produce the $\mathrm{m}^{7} \mathrm{GpCH}_{2} \mathrm{pp}$ p-aminophenyl $\gamma$-ester (11), which was then coupled to Sepharose $4 \mathrm{~B}$ using cyanogen bromide according to the protocol developed in Cuatrecasas et al. (1968). Using a similar procedure, we also synthesized Sepharoses substituted with $\mathrm{m}^{7} \mathrm{GTP}(\mathbf{1})$ and GTP as controls for the biological experiments.

The attachment of the dinucleotide cap analogs to the resin was performed according to the approach described in Lowe et al. (1972), which was used for the immobilization of nucleotide cofactors for dehydrogenase purification. To our knowledge, this is the first example of applying this synthetic approach to cap analog chemistry. In this case, the dinucleotides $\mathbf{1 8}$ and $\mathbf{1 9}$ were attached to the Sepharose via a 1,6-diaminohexane linker substituted at position 6 of adenosine $\left(\mathrm{A}^{\mathrm{N} 6-(\mathrm{CH} 2) 6 \mathrm{NH} 2}\right)$. The synthetic pathway leading to resins $\mathbf{3}$ and $\mathbf{4}$ is depicted in Figure 1B. The first step of the synthesis was the Yoshikawa phosphorylation of 6-chloropurine riboside (Yoshikawa et al. 1967), leading to 6-chloropurinoriboside 5'-monophosphate (6-ClAMP, 12). The introduction of the spacer to the ligand molecule was achieved by the substitution of 12 with 1,6-hexylenediamine as previously described (Huang et al. 2003). The reaction was performed in aqueous solution at room temperature using a 10-fold molar excess of the amine and led to the practically pure desirable product 13 within $2 \mathrm{~h}$ (98\% yield by HPLC). The introduction of a hydrophobic six-carbon atom chain with primary aliphatic amino group into nucleotide molecule changed its physicochemical properties, but did not significantly affect its reactivity in further synthetic steps, including conversion to the imidazole derivative, coupling to another nucleotide moiety, and immobilization on Sepharose. Dinucleotides 18 and 19 were obtained in a $\mathrm{ZnCl}_{2}$-catalyzed coupling reaction of 2-nt subunits, in which one subunit was activated as P-imidazolide (Mukaiyama and Hashimoto 1972; Kadokura et al. 1997; Stepinski et al. 2001; Jemielity et al. 2003; Kalek et al. 2006). The reaction of 13 with imidazole led to a moderately contaminated imidazolide derivative, which could not 
A

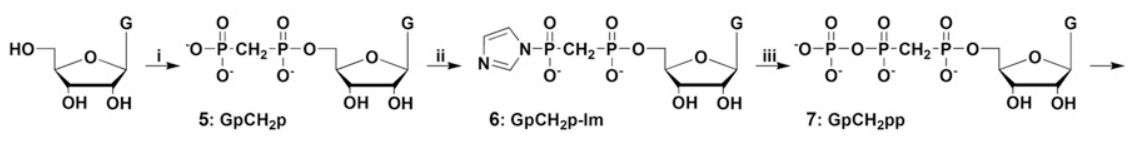

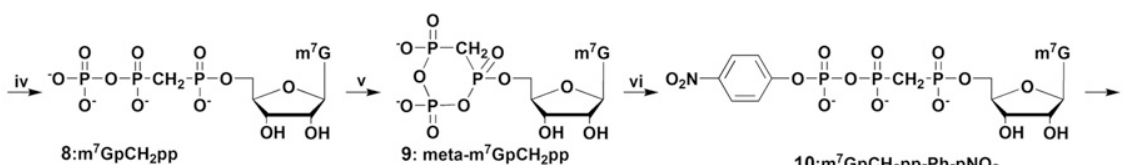

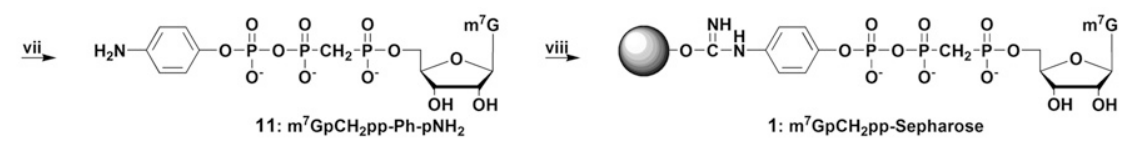

B

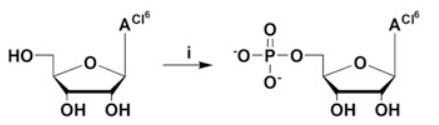

12: 6-CIAMP

ii,
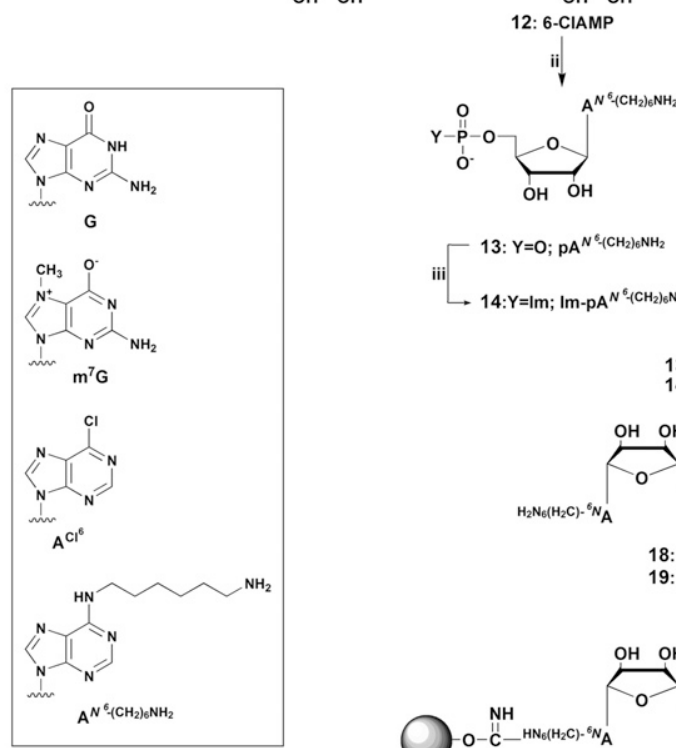

13: $Y=O ; \mathrm{pA}^{\mathrm{N}_{-}^{6}\left(\mathrm{CH}_{2}\right) \mathrm{NH}_{2}}$

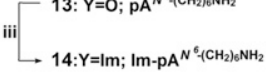

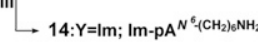

$13+17 \longrightarrow 18$
$14+15 \longrightarrow 19$

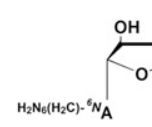

$$
\text { A }
$$

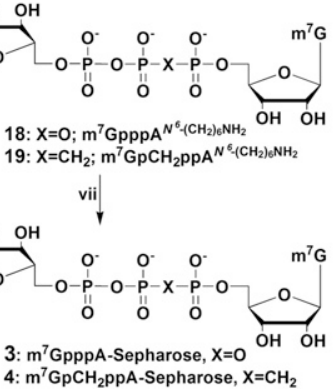

FIGURE 1. Synthesis of Sepharoses 2-4: (A) Synthesis of $\mathrm{m}^{7} \mathrm{GpCH}_{2} \mathrm{pp}$-Sepharose: (i) 1. $\mathrm{CH}_{2}\left(\mathrm{POCl}_{2}\right)_{2},\left(\mathrm{CH}_{3} \mathrm{O}\right)_{3} \mathrm{PO}$, 2. triethylamine bicarbonate (TEAB) aq.; (ii) imidazole, 2,2' -dithiodipiridine, $\mathrm{Ph}_{3} \mathrm{P}$, TEA, DMF; (iii) tris(triethylamine) phosphate, $\mathrm{ZnCl}_{2}$, DMF; (iv) $\mathrm{CH}_{3} \mathrm{I}, \mathrm{DMSO}$; (v) 1. tri-n-octylamine, $\mathrm{MeOH}, 2$. DCC, DMF; (vi) p-nitrophenol, TEA, DMF; (vii) Pd/C, $\mathrm{H}_{2}$, (viii) Sepharose 4B activated witch BrCN, sodium carbonate buffer ( $\mathrm{pH}$ 9.6). (B) Synthesis of $\mathrm{m}^{7} \mathrm{GpppA}-$ Sepharose and $\mathrm{m}^{7} \mathrm{GpCH}_{2} \mathrm{ppA}$-Sepharose: (i) 1. $\mathrm{POCl}_{3}, \quad\left(\mathrm{CH}_{3} \mathrm{O}\right)_{3} \mathrm{PO}, 2$. TEA/H $\mathrm{H}_{2} \mathrm{O}$; (ii) $\mathrm{NH}_{2}\left(\mathrm{CH}_{2}\right)_{6} \mathrm{NH}_{2}, \mathrm{H}_{2} \mathrm{O}$; (iii, v) imidazole, 2,2'-dithiodipiridine, $\mathrm{Ph}_{3} \mathrm{P}, \mathrm{Et}_{3} \mathrm{~N}$, DMF; (iv) $\mathrm{CH}_{3} \mathrm{I}, \mathrm{DMSO}$; (vi) $\mathrm{ZnCl}_{2}$, DMF; (vii) Sepharose $4 \mathrm{~B}$ activated witch $\mathrm{BrCN}$, sodium carbonate buffer (pH 9.6).

be purified due to its low stability in aqueous solution. Therefore, cap analog 18 was synthesized by the coupling of $\mathrm{m}^{7}$ GDP-Im (17) to 13. However, $\mathrm{m}^{7} \mathrm{GpCH}_{2} \mathrm{p}$-Im was even more difficult to obtain (yield below $5 \%$ in all tested conditions) and the opposite coupling strategy was used (Fig. 1B, step vi). Although the coupling reaction occurred with a significant accumulation of by-products, we were able to obtain pure cap analog 19 with a good preparative yield ( $42 \%$ total yield). Both nucleotides were then immobilized on cyanogen bromide-activated Sepharose 4B (Cuatrecasas et al. 1968). 2003).
The degrees of substitution (DS) to the resin were determined as described previously (Webb et al. 1984) by digestion of the immobilized ligands with two enzymes: alkaline phosphatase and phosphodiesterase I. The concentration of released nucleotides was measured spectrophotometrically at $260 \mathrm{~nm}$. The degree of substitution for Sepharose 2 could not be calculated, as this analog was not cleaved by either of the enzymes. The DS values for all tested resins were within the same range but lower than those described in Webb et al. (1984) (Table 1).

\section{Binding affinities to elF4E}

The binding affinities of synthesized dinucleotide cap analogs for mouse eIF4E $\mathrm{E}^{(28-217)}$ were determined by fluorescence quenching (Niedzwiecka et al. 2002). Comparison of the equilibrium association constant $\left(K_{A S}\right)$ values of different cap analogs with their unmodified counterparts (Table 2) shows that the affinity of the mononucleotide $\mathrm{m}^{7} \mathrm{GTP}$ was at least 10 -fold higher than that of the dinucleotide analogs (18-23). This probably resulted from a combination of increased electrostatic interactions between the pyrophosphate chain and the positively charged residues of the cap-binding pocket due to the additional negative charge on the terminal phosphate group (Zuberek et al. 2004) and the lack of steric hindrance. The presence of the second nucleoside in dinucleotides destabilizes the eIF4E-cap complex (Niedzwiecka et al. 2002). Introduction of the methylene group into the $5^{\prime}-5^{\prime}$-triphosphate bridge also decreases the affinity between cap analogs and eIF4E (Kalek et al. 2005a), this could be related to a change in the polyphosphate chain conformation and the net charge distribution which may disturb electrostatic interactions and hydrogen bond formation. Lack of a free electron pair is known to prevent methylene groups from forming hydrogen bonds, as observed in the crystal structure of the eIF4E- $\mathrm{m}^{7} \mathrm{GTP}$ complex (Niedzwiecka et al. 2002). The association constants of novel cap analogs (compounds 18 and 19) were much lower than those of their unmodified equivalents, but comparable to that of the model $\mathrm{A}^{6}$ substituted analog $\mathrm{m}^{7} \mathrm{Gpppm}^{6} \mathrm{~A}$ (Zuberek et al. 
TABLE 2. Comparison of equilibrium association constants $\left(\mathrm{K}_{A S}\right)$ for the binding of mouse elF4E $\mathrm{E}^{(28-217)}$ to cap analogs as determined by fluorescence quenching

\begin{tabular}{llcl}
\hline Compound & \multicolumn{1}{c}{ Cap analog } & \multicolumn{1}{c}{$K_{A S}\left[\mu \mathrm{M}^{-1}\right]$} & \multicolumn{1}{c}{ Ref } \\
\hline $\mathbf{1 8}$ & $\mathrm{m}^{7} \mathrm{GpppAN}{ }^{6} \mathrm{H}\left(\mathrm{CH}_{2}\right)_{6} \mathrm{NH}_{2}$ & $2.314 \pm 0.024$ & This work \\
$\mathbf{1 9}$ & $\mathrm{m}^{7} \mathrm{GpCH} \mathrm{H}_{2} \mathrm{ppAN} \mathrm{H}^{6}\left(\mathrm{CH}_{2}\right)_{6} \mathrm{NH}_{2}$ & $1.016 \pm 0.031$ & This work \\
& $\mathrm{m}^{7} \mathrm{Gpppm}{ }^{6} \mathrm{~A}$ & $3.9 \pm 0.2$ & (Zuberek et al. 2003) \\
& $\mathrm{m}^{7} \mathrm{GpppA}$ & $4.68 \pm 0.52$ & (Niedzwiecka et al. 2002) \\
& $\mathrm{m}^{7} \mathrm{GpppG}$ & $11.5 \pm 0.3$ & (Kalek et al. 2005a) \\
& $\mathrm{m}^{7} \mathrm{GpCH}{ }_{2} \mathrm{ppG}$ & $8.6 \pm 0.4$ & (Kalek et al. 2005a) \\
& $\mathrm{m}^{7} \mathrm{GTP}$ & $108.7 \pm 4.0$ & (Niedzwiecka et al. 2002) \\
& & &
\end{tabular}

It is noteworthy that the affinity of the immobilized cap analog may differ significantly from that of a free analog. For example, coupling to Sepharose through mononucleotide $p$-aminophenyl $\gamma$-ester eliminates the favorable effect of an additional negative charge on the terminal phosphate and generates steric hindrance by close proximity to the relatively bulky Sepharose bead. Conversely, immobilization of the dinucleotide cap analog via the 1,6-diaminohexane spacer arm may stabilize the eIF4E-cap complex by converting the spacer protonated terminal amino group into an isourea linkage, thus precluding a potentially destabilizing interaction of the linker with one of the cap's negatively charged phosphate groups. Moreover, the introduced linker separates the ligand from the Sepharose bead, which makes it more accessible for interactions with proteins.

\section{$\mathrm{m}^{7} \mathrm{GpCH}_{2}$ ppA-Sepharose binds DcpS specifically and with high affinity}

To determine the properties of the new resins, binding of recombinant mouse eIF4E $\mathrm{E}^{(28-217)}$ and human DcpS was evaluated. Proteins were incubated with equal volumes of $\mathrm{m}^{7} \mathrm{GpCH}_{2} \mathrm{pp}$-Sepharose (4), $\mathrm{m}^{7} \mathrm{GpppA}$-Sepharose (3), $\mathrm{m}^{7} \mathrm{GpCH}_{2} \mathrm{ppA}$-Sepharose (2), and control $\mathrm{m}^{7} \mathrm{GTP}$ Sepharose (1). Bound fractions were eluted with the free $\mathrm{m}^{7} \mathrm{GTP}$ cap analog $(1 \mathrm{mM})$ and precipitated from pooled eluates using pyrogallol red (Aguilar et al. 1999).

The efficiency of mouse eIF4E $\mathrm{E}^{(28-217)}$ binding was comparable for $\mathrm{m}^{7} \mathrm{GpCH}_{2} \mathrm{ppA}$-Sepharose (4) and standard $\mathrm{m}^{7} \mathrm{GTP}$-Sepharose (1) and significantly lower for the two other resins $(\mathbf{2}, \mathbf{3})$ (Fig. 2). This result was not consistent with the association values for different cap analogs (see Table 2); however, as discussed above, immobilized nucleotides do not necessarily have the same properties as their free counterparts. Remarkably, the only resin that bound human DcpS with high efficiency was the $\mathrm{m}^{7} \mathrm{GpCH}_{2} \mathrm{ppA}$ Sepharose (4) with a hexylene spacer linking the cap to the resin (Fig. 2). The other nonhydrolyzable, but mononucleotide, $\mathrm{m}^{7} \mathrm{GpCH}_{2}$ pp-Sepharose (2) had a much lower affinity for hDcpS, probably due to the restricted access to the enzyme binding pocket, which is located within a deep cleft ( $\mathrm{Gu}$ et al. 2004). The binding capacity of the $\mathrm{m}^{7} \mathrm{GpCH}_{2} \mathrm{ppA}$-Sepharose (4) was probably further increased by the incorporation of a dinucleotide analog, based on the structural data showing that hDcpS interacts not only with the 7-methylguanosine moiety, but also with the second nucleobase of the cap structure ( $\mathrm{Gu}$ et al. 2004).

\section{Purification of cap-binding proteins from yeast extract}

To further test the new resins, their applicability for the purification of capbinding proteins from cellular extracts was assessed. The $\mathrm{m}^{7}$ GTP-Sepharose (1), GTP-Sepharose, and unmodified CNBr-activated Sepharose $4 \mathrm{~B}$ were used as positive and negative controls.

Resins were incubated with crude yeast extract under saturating conditions in the presence of $0.1 \%$ Triton X100 and $100 \mu \mathrm{M}$ of GTP to minimize unspecific interactions. Bound proteins were eluted with the free $\mathrm{m}^{7} \mathrm{GTP}$ cap analog $(100 \mu \mathrm{M})$, precipitated with pyrogallol red, and analyzed by tandem mass spectrometry (Brooks et al. 2010).

Approximately 200 different proteins were identified in each eluate (Supplemental Table S1) by tandem mass spectrometry. The highest scored hits specific for $\mathrm{m}^{7} \mathrm{GTP}$ Sepharose (1), $\mathrm{m}^{7} \mathrm{GpppA}$-Sepharose (3), and $\mathrm{m}^{7} \mathrm{GpCH}_{2} \mathrm{ppA}$ Sepharose (4) that were not represented in both negative control eluates are listed in Table 3.

All eluates from cap analog modified resins contained both major cap-binding complexes, eIF4F consisting of the cap-binding protein eIF4E, one of the two eIF4G isoforms and one of the two eIF4A isoforms, as well as CBC composed of cap-binding proteins $\mathrm{Cbp} 20$ and $\mathrm{Cbp} 80$, with either Cbp80 or eIF4G1 as the highest scored hits. Only $\mathrm{m}^{7} \mathrm{GpCH}_{2} \mathrm{ppA}$-Sepharose (4) was able to bind the yeast DcpS homolog, Dcs1 (Table 3), which is consistent with binding studies for recombinant DcpS (see Fig. 2).

Although several nucleotide-binding proteins and some housekeeping proteins were also retained on cap

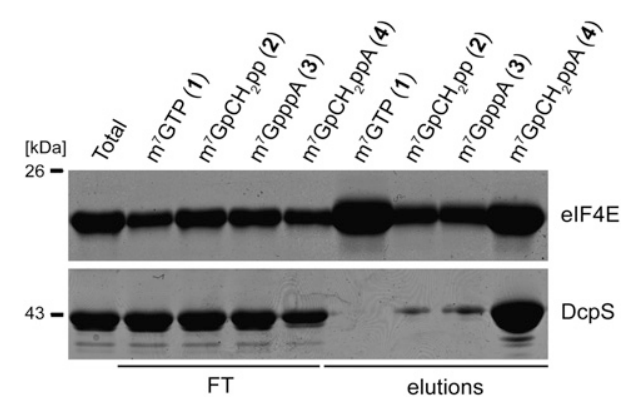

FIGURE 2. Binding of recombinant mouse eIF4E $\mathrm{E}^{(28-217)}$ and human DcpS to $\mathrm{m}^{7} \mathrm{GTP}$-Sepharose (1), $\mathrm{m}^{7} \mathrm{GpCH}_{2}$ pp-Sepharose (2), $\mathrm{m}^{7} \mathrm{GpppA}$ Sepharose (3), and $\mathrm{m}^{7} \mathrm{GpCH}_{2} \mathrm{ppA}$-Sepharose (4). Coomasie bluestained SDS-PAGE of total, flow-through (FT), and bound fractions eluted with $1 \mathrm{mM} \mathrm{m}^{7} \mathrm{GTP}$. 
TABLE 3. Purification of cap-binding proteins from yeast extract

\begin{tabular}{lrrr}
\hline Protein & \multicolumn{1}{c}{$\mathrm{m}^{7} \mathrm{GTP}$} & $\mathrm{m}^{7} \mathrm{GpppA}$ & $\mathrm{m}^{7} \mathrm{GpCH}_{2} \mathrm{ppA}$ \\
\hline Cbp80 & $11,157.0(59)$ & $6934.0(52)$ & $405.0(6)$ \\
Cbp20 & $1436.0(12)$ & $1010.0(12)$ & $72.0(1)$ \\
elF4G1 & $5280.0(45)$ & $1736.0(30)$ & $1817.0(30)$ \\
elF4G2 & $2522.0(35)$ & $696.0(14)$ & $533.0(13)$ \\
elF4A1/2 & $451.0(8)$ & $315.0(8)$ & $247.0(6)$ \\
elF4E & $264.0(7)$ & $1203.0(8)$ & $247.0(6)$ \\
Dcs1 & & & $216.0(4)$ \\
Ssb2 & $1828.0(22)$ & $1844.0(24)$ & $1584.0(20)$ \\
Eap1 & $532.0(10)$ & & $147.0(3)$ \\
Nab3 & $205.0(5)$ & $208.0(6)$ & \\
Nrd1 & $131.0(2)$ & $78.0(1)$ & \\
Sse1 & $101.0(2)$ & $108.0(2)$ & $153.0(5)$ \\
Npl3 & $60.0(1)$ & $103.0(2)$ & $62.0(1)$ \\
\hline
\end{tabular}

Set of proteins with the highest scores that were specifically bound to $\mathrm{m}^{7}$ GTP-, $\mathrm{m}^{7} \mathrm{GpppA}$-, and $\mathrm{m}^{7} \mathrm{GpCH}_{2}$ ppA-Sepharoses, as identified by tandem mass spectrometry following subtraction of peptides obtained in controls to account for unspecific hits. MS-MS analysis was performed on samples from whole eluates. Main numbers represent MS/MS protein identification scores; figures in parentheses show numbers of identified peptides.

analog resins, this probably resulted from unspecific binding, as they were also present in eluates from GTP-Sepharose and unmodified Sepharose 4B controls (Supplemental Table S1).

The remaining proteins that were specifically recovered from cap analog-modified Sepharoses were either well-known or possible binding partners of cap-binding complexes. Most of them are involved in RNA metabolism, including regulation of translation (eIF4E associated protein Eap1) (Cosentino et al. 2000), mRNA nuclear export (Npl3, reported to interact with CBC) (Shen et al. 2000), or transcription termination (Nrd1/Nab3 complex, potentially interacting with CBC) (Vasiljeva and Buratowski 2006). Unexpectedly, the $\mathrm{m}^{7} \mathrm{GpCH}_{2} \mathrm{pp}$-Sepharose had the lowest specificity for yeast cap-binding complexes (Supplemental Table S1) but efficiently bound the L-A yeast virus capsid protein, which was recovered using all resins (Szczepaniak et al. 2008) (Supplemental Table S1), most likely due to its decapping activity (Blanc et al. 1992).

To obtain more quantitative information concerning the relative efficiency of binding to different cap analogs we performed similar experiments using yeast strains expressing tagged yeast cap-binding proteins, eIF4E and Cbp20. eIF4E was expressed from a plasmid under the control of the $\mathrm{P}_{G A L}$ promoter as a $\mathrm{C}$-terminal fusion with a triple affinity tag consisting of a $\mathrm{His}_{6}$-HA epitope, a protease $3 \mathrm{C}$ cleavage site, and the IgG domain of protein A (Gelperin et al. 2005). Cbp20 was expressed under its endogenous promoter in a fusion with the C-terminal Myc epitope (Wong et al. 2007). Eluted proteins were resolved by SDSPAGE and subjected to Western blot analysis (Fig. 3).

The level of eIF4E was similar in all four eluates (Fig. 3), which is consistent with the MS-MS data, assuming that the number of identified peptides corresponds to the amount of protein (see Table 3; Supplemental Table S1). These results differ significantly from binding studies with mouse eIF4E $\mathrm{E}^{(28-217)}$ that show a comparably high capacity of resins $\mathbf{1}$ and $\mathbf{4}$ and comparable, but lower, capacity of resins $\mathbf{2}$ and 3. This discrepancy may result from structural differences between yeast and mammalian eIF4E, which in turn affects protein-cap complex stability (Niedzwiecka et al. 2002; Kiraga-Motoszko et al. 2003).

In turn, Cbp20 bound with a comparable high affinity to the control $\mathrm{m}^{7} \mathrm{GTP}-$ Sepharose (1) and the newly synthesized $\mathrm{m}^{7} \mathrm{GpppA}$-Sepharose (3). The eluates from $\mathrm{m}^{7} \mathrm{GpCH}_{2} \mathrm{pp}-$ Sepharose (2) and $\mathrm{m}^{7} \mathrm{GpCH}_{2} \mathrm{ppA}$-Sepharose (4) showed a much lower level of Cbp20, which is in agreement with the MS-MS data (maximum only one peptide identified for Cbp20) (see Table 3; Supplemental Table S1). This feature of resins $\mathbf{2}$ and $\mathbf{4}$ may be regarded as an advantage, as these resins were designed especially for purification of DcpS.

\section{General conclusions}

Efficient syntheses of three novel affinity resins with attached cap analogs are described and as the developed methodology is general, it can be applied to the synthesis of other resins carrying different cap analogs, which may specifically and differentially bind various cap-binding proteins. One such example is a group of dinucleotide analogs with increased length of the $5^{\prime}-5^{\prime}$ triphosphate bridge, which has been shown to bind eIF4E with higher affinity (Niedzwiecka et al. 2002). All synthesized resins specifically bind cap-binding proteins, either recombinant or from complex biological samples such as crude yeast extract. $\mathrm{m}^{7} \mathrm{GpCH}_{2} \mathrm{pp}$-Sepharose (2) and $\mathrm{m}^{7} \mathrm{GpCH}_{2} \mathrm{ppA}-$ Sepharose (4) are both resistant to hydrolysis by DcpS due to the methylene modification. However, only $\mathrm{m}^{7} \mathrm{GpCH}_{2} \mathrm{ppA}-$ Sepharose (4) efficiently binds this protein due to the introduction of a hexylene spacer arm that separates the cap analog from the bulky Sepharose bead. On the other

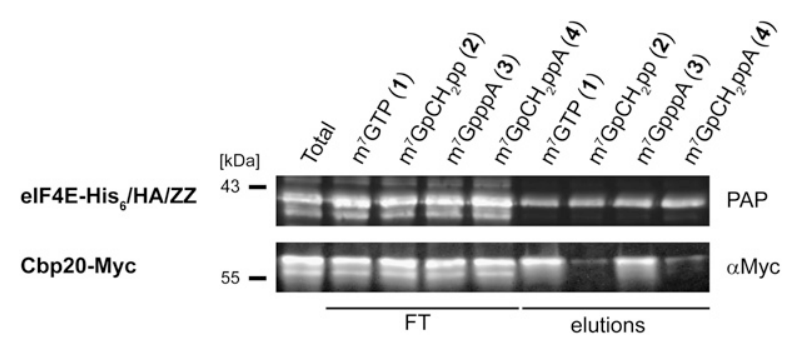

FIGURE 3. A Western blot of eIF4E-His ${ }_{6} / \mathrm{HA} / \mathrm{ProtA}$ and Cbp20-Myc purified from yeast extract using $\mathrm{m}^{7} \mathrm{GTP}$-Sepharose, $\mathrm{m}^{7} \mathrm{GpCH}_{2} \mathrm{pp}-$ Sepharose, $\mathrm{m}^{7}$ GpppA-Sepharose, eluted with $1 \mathrm{mM} \mathrm{m}^{7} \mathrm{GTP}$ and detected with PAP and anti-Myc antibodies, respectively. Western blot was performed on total lysate (Total), flow trough (FT), and elutions from each resin. 
hand, resins 2 and 4 seem to be relatively less specific toward other cap-binding proteins, especially $\mathrm{CBC}$, which in turn makes them good tools for the isolation or identification of cap-specific pyrophosphatases from different organisms.

\section{MATERIALS AND METHODS}

\section{Chemical synthesis}

\section{General procedures}

Solvents and other reagents (excluding guanosine and 6-chloropurine riboside) were purchased from Sigma-Aldrich and used without further treatment unless otherwise stated. Sodium salts of commercially available nucleotides were converted into triethylammonium salts by passing through Dowex 50 WX8/TEA form, evaporating collected fractions to dryness, and drying in a vacuum over $\mathrm{P}_{2} \mathrm{O}_{5}$. Tris(triethylamine) phosphate was prepared in the same way from sodium phosphate. Guanosine 5' -diphosphate (TEA salt), GTPSepharose, and $\mathrm{m}^{7} \mathrm{GTP}$-Sepharose (1) were synthesized as described previously (Webb et al. 1984; Darzynkiewicz et al. 1985; Jemielity et al. 2003).

The intermediate nucleotides were purified by ion-exchange chromatography on a DEAE-Sephadex A-25 $\left(\mathrm{HCO}_{3}{ }^{-}\right.$form $)$ column using a linear gradient of triethylammonium bicarbonate (TEAB) in deionized water. The eluates containing the product, as followed by UV adsorption measurement at $260 \mathrm{~nm}$, were pooled and after evaporation under reduced pressure with repeated addition of ethanol and drying in a vacuum dessicator over $\mathrm{P}_{2} \mathrm{O}_{5}$, were isolated as triethylammonium salts.

Monitoring of the reaction progress as well as the purity of intermediates was performed by analytical HPLC on the Agilent Technologies Series 1200 apparatus using Supelcosil LC-18-T RP column $(4.6 \times 250 \mathrm{~mm}$, flow rate $1.3 \mathrm{~mL} / \mathrm{min})$ developed with a linear gradient $0 \%-100 \%$ of methanol in $0.05 \mathrm{M}$ ammonium acetate buffer ( $\mathrm{pH}$ 5.9) within $30 \mathrm{~min}$ (gradient 1) or $15 \mathrm{~min}$ (gradient 2), UV-detection at $260 \mathrm{~nm}$, and fluorescence detection (excitation at $280 \mathrm{~nm}$ and detection at $337 \mathrm{~nm}$ ).

The final nucleotide products $(\mathbf{1 8}, \mathbf{1 9})$ were purified by the Semi-preparative HPLC Waters 600E Multisolvent Delivery System using Waters HR-C-18 HPLC column $(300 \times 19 \mathrm{~mm}, 6 \mu \mathrm{m}$, flow rate $5.0 \mathrm{~mL} / \mathrm{min}$ ) with linear gradient of methanol in $0.05 \mathrm{M}$ ammonium acetate buffer ( $\mathrm{pH} 5.9$ ) and UV-detection at $260 \mathrm{~nm}$. After repeated freeze-drying, the products were isolated as ammonium salts.

The yields were calculated based on the optical density miliunits at $260 \mathrm{~nm}\left(\mathrm{mODU}_{260}\right)$ of substrates and isolated products, measured in $0.1 \mathrm{M}$ phosphate buffer $(\mathrm{pH} \mathrm{6})$ for $\mathrm{m}^{7}$ Guo mononucleotides, or $\mathrm{pH} 7$ for cap dinucleotides and Guo nucleotides. The optical density miliunits $\mathrm{mODU}_{260}$ are defined as absorption of compound solution in $0.1 \mathrm{M}$ phosphate buffer of appropriate $\mathrm{pH}$ at $260 \mathrm{~nm}$, multiplied by the volume of the solution (milliliters). The extinction coefficients taken for calculations were $\varepsilon_{260}(\mathrm{pH}=7)=10,400 \mathrm{M}^{-1} \mathrm{~cm}^{-1}$ or $\varepsilon_{260}(\mathrm{pH}=6)=$ $11,400 \mathrm{M}^{-1} \mathrm{~cm}^{-1}$ for $\mathrm{m}^{7}$ Guo mononucleotides, $\varepsilon_{260}(\mathrm{pH}=7)=$ $12,000 \mathrm{M}^{-1} \mathrm{~cm}^{-1}$ for Guo mononucleotides, $\varepsilon_{260}(\mathrm{pH}=7)=9750$ $\mathrm{M}^{-1} \mathrm{~cm}^{-1}$ for 6-ClAMP (12), and $\varepsilon_{260}(\mathrm{pH}=7)=15,000 \mathrm{M}^{-1}$ $\mathrm{cm}^{-1}$ for N6 substituted adenosine derivatives. For cap dinucleotides the extinction coefficient was calculated from the equation: $\varepsilon=0.9 \times\left(\varepsilon_{1}+\varepsilon_{2}\right)$, where $\varepsilon_{1}$ and $\varepsilon_{2}$ represent extinction coefficients of both nucleotides subunits.

The structure and homogeneity of each final product was confirmed by rechromatography on RP HPLC, mass spectrometry using negative electrospray ionization (MS ESI-), and ${ }^{1} \mathrm{H}$ NMR and ${ }^{31} \mathrm{P}$ NMR spectroscopy. ${ }^{1} \mathrm{H}$ NMR and ${ }^{31} \mathrm{P}$ NMR spectra were recorded in $\mathrm{D}_{2} \mathrm{O}$ at $25^{\circ} \mathrm{C}$ on a Varian UNITY-plus spectrometer at $399.94 \mathrm{MHz}$ and $161.90 \mathrm{MHz}$, respectively. ${ }^{1} \mathrm{H}$ NMR chemical shifts in ppm were reported to sodium 3-trimethylsilyl-[2,2,3,3-D4]-propionate (TSP) in $\mathrm{D}_{2} \mathrm{O}$ as an internal standard. ${ }^{31} \mathrm{P}$ NMR chemical shifts in ppm were reported to $20 \%$ phosphorus acid in $\mathrm{D}_{2} \mathrm{O}$ as an external standard. Coupling constants $(J)$ are given in hertz. Mass spectra were recorded on a Micromass QToF 1 MS spectrometer.

P1-(guanosin-5'-yl) 1,2-methylenediphosphate, $\mathrm{GpCH}_{2} \mathrm{p}$ (5). Phosphonylation of guanosine with methylenebis-(phosphonic dichloride) was achieved by the modified Yoshikawa procedure as described in the literature (Kalek et al. 2005b). Guanosine (1.27 g, $4.5 \mathrm{mmol}$ ) was suspended in $10 \mathrm{~mL}$ of trimethyl phosphate and cooled to $0^{\circ} \mathrm{C}$. Pre-cooled solution of methylenebis(phosphonic dichloride) (2.26 g, $9 \mathrm{mmol})$ in trimethyl phosphate $(2 \mathrm{~mL})$ was added to the stirring mixture. Reaction was performed at $0^{\circ} \mathrm{C}$, and after $1.5 \mathrm{~h}$, when the reaction was completed (assigned by analytical HPLC), it was stopped by the addition of $0.7 \mathrm{M}$ TEAB to $\mathrm{pH}$ 7. Product purification was carried out by ion-exchange chromatography on DEAE-Sephadex with 0-1.05 M linear gradient of TEAB to yield 21,400 mODU $_{260}(1.78 \mathrm{mmol}, 39 \%)$ of 5 as a TEA salt. HPLC (gradient 1) $\mathrm{R}_{\mathrm{t}}=3.7 \mathrm{~min}$, ESI MS (-) $\mathrm{m} / z 440.0$ (calc. for $\mathrm{C}_{11} \mathrm{H}_{16} \mathrm{~N}_{5} \mathrm{O}_{10} \mathrm{P}_{2}$ : 440.0).

P1-guanosin-5'-yl 1,2-methylenediphosphate P2-imidazolide, $\mathrm{GpCH}_{2} \mathrm{p}$-Im (6). Imidazolides were prepared according to the previously described procedure (Jemielity et al. 2003) with several modifications. $\mathrm{GpCH}_{2} \mathrm{p}$ (5) (225 mg; $0.51 \mathrm{mmol}$, TEA salt), imidazole (699 mg, $10.3 \mathrm{mmol}), 2,2^{\prime}$-dithiodipyridine $(678 \mathrm{mg}$, $4.1 \mathrm{mmol}$ ) were mixed in anhydrous DMF $(6 \mathrm{~mL})$. Triethylamine $(569 \mu \mathrm{L}, 3.1 \mathrm{mmol})$ and triphenylphosphine $(415 \mathrm{mg}, 4.1 \mathrm{mmol})$ were added and the mixture was stirred for $24 \mathrm{~h}$. The product was precipitated from a reaction mixture with a solution of anhydrous $\mathrm{NaClO}_{4}$ (3 eq. per one negative charge) in dry acetone $(\sim 8 \mathrm{~mL} / 1$ $\mathrm{mL}$ of DMF). After cooling at $4^{\circ} \mathrm{C}$, the precipitate was settled by centrifugation $\left(4000 \mathrm{~g}\right.$ at $\left.4^{\circ} \mathrm{C}\right)$, washed repeatedly with cold, dry acetone and dried in a vacuum over $\mathrm{P}_{4} \mathrm{O}_{10}$. A total of $210 \mathrm{mg}$ of $\mathrm{GpCH}_{2} \mathrm{p}$-Im (6) (0.39 mmol, 77\% yield) was obtained. Analytical RP HPLC (gradient 1) $\mathrm{R}_{\mathrm{t}}=4.8 \mathrm{~min}$.

P1-guanosin-5'-yl 1,2-methylenetriphosphate, $\mathrm{GpCH}_{2} \mathrm{pp}$ (7). $\mathrm{GpCH}_{2} \mathrm{pp}$ (7) was prepared as previously described (Rydzik et al. 2009). $\mathrm{GpCH}_{2} \mathrm{p}-\mathrm{Im}(6)(250 \mathrm{mg}, 0.47 \mathrm{mmol})$, tris(triethylamine) phosphate (575 $\mathrm{mg}, 1.86 \mathrm{mmol})$, and $\mathrm{ZnCl}_{2}$ (1.1 g, 7.4 $\mathrm{mmol}$ ) were mixed in anhydrous DMF $(4 \mathrm{~mL})$ and stirred at room temperature for $3 \mathrm{~h}$ until the HPLC analysis showed the reaction was completed. To stop the reaction, a solution of EDTA (1 eq./1 eq. of $\mathrm{ZnCl}_{2}$ ) in water was added and $\mathrm{pH}$ was brought to 7 by addition of solid $\mathrm{NaHCO}_{3}$. The product (7) was purified as TEA salt using DEAE-Sephadex in a linear $0-1.2 \mathrm{M}$ gradient of TEAB to yield $3070 \mathrm{mODU}_{260}(0.26 \mathrm{mmol}, 54 \%)$. Analytical HPLC (gradient 1) $\mathrm{R}_{\mathrm{t}}=2.4 \mathrm{~min}$.

P1-(7-methylguanosin-5'-yl) 1,2-methylenetriphosphate, $\mathrm{m}^{7} \mathrm{GpCH}_{2} \mathrm{pp}$ (8). Methylation of guanosine moiety leading to 
$\mathrm{m}^{7} \mathrm{G}$ derivatives was performed as previously described (Jemielity et al. 2003). A total of $3070 \mathrm{mODU}_{260} \mathrm{GpCH}_{2} \mathrm{pp}$ (7) $(0.26 \mathrm{mmol})$ and $303 \mu \mathrm{L}$ (682 mg, $4.8 \mathrm{mmol}$ ) of $\mathrm{CH}_{3} \mathrm{I}$ was dissolved in DMSO $(8 \mathrm{~mL})$ and stirred for $5 \mathrm{~h}$; when the reaction was completed (assigned by analytical HPLC), the mixture was diluted with water $(200 \mathrm{~mL})$ and extracted with diethyl ether $(4 \times 150 \mathrm{~mL})$. Solid $\mathrm{Na}_{2} \mathrm{~S}_{2} \mathrm{O}_{5}$ was added until the solution turned colorless and the remaining ether was evaporated under reduced pressure. The product (8) (886 $\mathrm{mODU}_{260}, 0.09 \mathrm{mmol}, 35 \%$ yield) was isolated as TEA salt on DEAE Sephadex using a linear 0-1.1 M gradient of TEAB. HPLC (gradient 1) $\mathrm{R}_{\mathrm{t}}=2.9 \mathrm{~min}$.

P1-(7-methylguanosin-5'-yl) 1,2-methylenetrimetaphosphate, meta- $\mathrm{m}^{7} \mathrm{GpCH} \mathrm{H}_{2} \mathrm{pp}$ (9). Introduction of reactive nitro group into the nucleotide was obtained following procedure of Webb et al. (1984). A solution of $\mathrm{m}^{7} \mathrm{GpCH}_{2} \mathrm{pp}$ (8) (1310 $\mathrm{mODU}_{260}, 0.126$ $\mathrm{mmol})$ in methanol $(3 \mathrm{~mL})$ was treated with tri- $n$-octylamine $(0.17 \mathrm{~mL}, 0.38 \mathrm{mmol})$ and stirred at room temperature until a clear solution was obtained $(\sim 1 \mathrm{~h})$. The solvent was evaporated under reduced pressure and the tri- $n$-octylammonium salt of $\mathrm{m}^{7} \mathrm{GpCH}_{2}$ pp dried under vacuum with dry DMF $(3 \times 1 \mathrm{~mL})$. The dried product was dissolved in anhydrous DMF/methanol (9:1 $\mathrm{v} / \mathrm{v}, 4.4 \mathrm{~mL})$, treated with dicyclohexylcarbodiimide $(189 \mathrm{mg}$, $0.9 \mathrm{mmol}$ ), and stirred overnight at room temperature in a desiccator. The solvent was evaporated under reduced pressure at the end of the reaction; 9 was obtained as a dense, oily liquid that was directly used in the next step of the synthesis. HPLC (gradient 1) $\mathrm{R}_{\mathrm{t}}=5.4 \mathrm{~min}$ and $5.8 \mathrm{~min}$.

P1-(7-methylguanosin-5'-yl) 4-nitrophenyl-(1,2-methylenetriphosphate), $\mathrm{p}-\mathrm{NO}_{2}-\mathrm{Ph}-\mathrm{m}^{7} \mathrm{GpCH} \mathrm{H}_{2} \mathrm{pp}$ (10). Synthesis of $\mathbf{1 0}$ was performed as previously described (Webb et al. 1984) with some major modifications. meta- $\mathrm{m}^{7} \mathrm{GpCH}_{2} \mathrm{pp} \quad$ (9) $(\sim 0.126 \mathrm{mmol})$, p-nitrophenol (425 mg, $0.3 \mathrm{mmol})$, and triethylamine $(406 \mu \mathrm{L}$, $0.3 \mathrm{mmol}$ ) were dissolved in dry DMF $(4.4 \mathrm{~mL})$. The reaction mixture was tightly stoppered and stirred for $6 \mathrm{~d}$ at $50^{\circ} \mathrm{C}$ (the reaction progress was monitored by HPLC). The reaction mixture was then diluted with water $(15 \mathrm{~mL})$, cooled, and the $\mathrm{pH}$ was adjusted to 3.5 with $\mathrm{HCl}$. The mixture was extracted with ether $(2 \times 25 \mathrm{~mL})$ and the aqueous layer was neutralized with $\mathrm{NaHCO}_{3}$. The product was purified on DEAE-Sephadex in a linear $0-0.7 \mathrm{M}$ gradient of TEAB; 10 was obtained as TEA salt to yield 603 $\mathrm{mODU}_{260}(0.06 \mathrm{mmol}, 46 \%)$. HPLC (gradient 1$) \mathrm{R}_{\mathrm{t}}=8.15 \mathrm{~min}$. ESI MS (-) $m / z 655.0$ (calc. for $\mathrm{C}_{18} \mathrm{H}_{22} \mathrm{~N}_{6} \mathrm{O}_{15} \mathrm{P}_{3}$ : 655.0). $\delta_{\mathrm{H}} 8.20$ $\left(2 \mathrm{H}, \mathrm{d}, J_{2 \mathrm{Ph}, 3 \mathrm{Ph}}=J_{5 \mathrm{Ph}, 6 \mathrm{Ph}} 8.6, \mathrm{H} 3_{\mathrm{Ph}}, \mathrm{H} 5_{\mathrm{Ph}}\right) ; 7.35\left(2 \mathrm{H}, \mathrm{d}, J 2 \mathrm{Ph}, 3_{\mathrm{Ph}}=\right.$ $\left.J 5_{\mathrm{Ph}}, 6_{\mathrm{Ph}} 8.6, \mathrm{H} 2_{\mathrm{Ph}}, \mathrm{H} 6_{\mathrm{Ph}}\right) ; 5.99\left(1 \mathrm{H}, \mathrm{d}, J_{1^{\prime}, 2^{\prime}} 4.0, \mathrm{H} 1^{\prime}\right) ; 4.63(1 \mathrm{H}$, $\left.\mathrm{dd}, J_{1^{\prime}, 2^{\prime}} 4.0, J_{2^{\prime}, 3^{\prime}} 4.7, \mathrm{H} 2^{\prime}\right) ; 4.52\left(1 \mathrm{H}, \mathrm{dd}, J_{2^{\prime}, 3^{\prime}} 4.7, J_{3^{\prime}, 4^{\prime}} 5.3, \mathrm{H}^{\prime}\right)$; $4.36\left(1 \mathrm{H}, \mathrm{m}, \mathrm{H} 4^{\prime}\right) ; 4.32\left(1 \mathrm{H}, \mathrm{m}, \mathrm{H} 5^{\prime}\right) ; 4.20\left(1 \mathrm{H}, \mathrm{m}, \mathrm{H} 5^{\prime \prime}\right) ; 4.08$ $\left(3 \mathrm{H}, \mathrm{s},-\mathrm{CH}_{3}\right) ; 2.42\left(2 \mathrm{H}, \mathrm{dt}, J_{\mathrm{P} \beta,-\mathrm{CH} 2-}=J_{\mathrm{P} \gamma,-\mathrm{CH} 2-} 20.6,-\mathrm{CH}_{2^{-}}\right) . \delta_{\mathrm{P}}$ $17.38\left(1 \mathrm{P}, \mathrm{m}, \mathrm{P}_{\gamma}\right) ; 8.01\left(1 \mathrm{P}, \mathrm{m}, \mathrm{P}_{\beta}\right) ;-16.55\left(1 \mathrm{P}, \mathrm{d}, J_{\alpha, \beta} 25.6, \mathrm{P}_{\alpha}\right)$.

P1-(7-methylguanosin-5'-yl) 4-aminophenyl-(1,2-methylenetriphosphate), $\mathrm{p}-\mathrm{NH}_{2}-\mathrm{Ph}-\mathrm{m}^{7} \mathrm{GpCH}_{2} \mathrm{pp}$ (11). Synthesis of 11 was performed as previously described (Webb et al. 1984) with few modifications. p- $\mathrm{NO}_{2}-\mathrm{Ph}-\mathrm{m}^{7} \mathrm{GpCH} 2 \mathrm{pp}$ (10) (600 mODU $\mathrm{m}_{260}$, $0.06 \mathrm{mmol}$ ) was dissolved in $\mathrm{H}_{2} \mathrm{O}(8.4 \mathrm{~mL})$ and reduced by the method described previously (Berglund and Eckstein 1972). Argon was bubbled through the solution, after which palladium on charcoal $(150 \mathrm{mg}$ ) was added. Hydrogen gas was bubbled through the suspension for $3 \mathrm{~h}$. The reaction mixture was then filtered and the catalyst washed repeatedly with water. The filtrate and combined washings were concentrated by partial evaporation of water under reduced pressure; 11 was obtained to yield $355 \mathrm{mODU}_{260}$ ( $0.034 \mathrm{mmol}, 59 \%)$, and without further purification was coupled to Sepharose 4B. HPLC (gradient 1) $\mathrm{R}_{\mathrm{t}}=4.4 \mathrm{~min}$. ESI MS (-) $\mathrm{m} / \mathrm{z} 625.1$ (calc. for $\mathrm{C}_{18} \mathrm{H}_{24} \mathrm{~N}_{6} \mathrm{O}_{13} \mathrm{P}_{3}$ : 625.1). $\delta_{\mathrm{H}} 9.37$ (s, $\mathrm{H} 8_{\mathrm{m} 7 \mathrm{G}}$ ); $7.02(2 \mathrm{H}$, d, $\left.J_{2 \mathrm{Ph}, 3 \mathrm{Ph}}=J_{5 \mathrm{Ph}, 6 \mathrm{Ph}} 8.2, \mathrm{H} 3_{\mathrm{Ph}}, \mathrm{H} 5_{\mathrm{Ph}}\right) ; 6.88\left(2 \mathrm{H}, \mathrm{d}, J_{2 \mathrm{Ph}, 3 \mathrm{Ph}}=J_{5 \mathrm{Ph}, 6 \mathrm{Ph}} 8.2\right.$, $\left.\mathrm{H} 2_{\mathrm{Ph}}, \mathrm{H}_{\mathrm{Ph}}\right) ; 6.02\left(1 \mathrm{H}, \mathrm{d}, J_{1^{\prime}, 2^{\prime}} 3.5, \mathrm{H1}^{\prime}\right) ; 4.71\left(1 \mathrm{H}, \mathrm{m}, \mathrm{H} 2^{\prime}\right) ; 4.55(1 \mathrm{H}$, $\left.\mathrm{m}, \mathrm{H}^{\prime}\right)$; 4.39 (1H, m, H4'); $4.27\left(1 \mathrm{H}, \mathrm{m}, \mathrm{H} 5^{\prime}\right)$; 4.17 (1H, m, H5' '); $4.09\left(3 \mathrm{H}, \mathrm{s},-\mathrm{CH}_{3}\right) ; 2.39\left(2 \mathrm{H}, \mathrm{t}, J_{\mathrm{PB},-\mathrm{CH} 2-}=J_{\mathrm{P} \gamma,-\mathrm{CH} 2-} 20.3,-\mathrm{CH}_{2}-\right) . \delta_{\mathrm{P}}$ $17.61\left(1 \mathrm{P}, \mathrm{m}, \mathrm{P}_{\gamma}\right) ; 7.89\left(1 \mathrm{P}, \mathrm{m}, \mathrm{P}_{\beta}\right) ;-14.81\left(1 \mathrm{P}, \mathrm{d}, J_{\alpha, \beta} 24.6 \mathrm{P}_{\alpha}\right)$.

Activation of Sepharose 4B with CNBr. Activation reaction was performed by the procedure described before (Cuatrecasas et al. 1968; Webb et al. 1984). Washed and settled Sepharose 4B (GE Healthcare) was suspended in an equal volume of water. The suspension was stirred at $4^{\circ} \mathrm{C}$. A solution of cyanogen bromide $(1.8 \mathrm{~mL}$ of a $1 \mathrm{~g} / \mathrm{mL}$ solution for $15 \mathrm{~mL}$ of settled Sepharose) in acetonitrile was added, and the $\mathrm{pH}$ was maintained between 11 and 11.5 by addition of $1 \mathrm{M}$ $\mathrm{NaOH}$ for $\sim 30 \mathrm{~min}$. The resin was then filtered and washed with $\mathrm{H}_{2} \mathrm{O}$ ( $1 \mathrm{~L}$ for $15 \mathrm{~mL}$ of Sepharose) and cold $0.1 \mathrm{M} \mathrm{NaHCO}-\mathrm{Na}_{2} \mathrm{CO}_{3}$ buffer ( $\mathrm{pH}$ 9.0, $1 \mathrm{~L}$ ). The washed resin was suspended in an equal volume of buffer and treated with the appropriate cap analog.

P1-(7-methylguanosin-5'-yl) 1,2-methylenetriphosphate Sepharose, $\mathrm{m}^{7} \mathrm{GpCH}_{2} \mathrm{pp}$-Sepharose (2). Coupling reaction was performed as described before (Cuatrecasas et al. 1968, Webb et al. 1984). A total of $6 \mathrm{~mL}$ (settled volume) of $\mathrm{CNBr}$ activated Sepharose $4 \mathrm{~B}$ resuspended in cold $0.1 \mathrm{M} \mathrm{NaHCO}-\mathrm{Na}_{2} \mathrm{CO}_{3}$ buffer ( $\mathrm{pH}$ 9.0, $8 \mathrm{~mL})$ was treated with $100 \mathrm{mODU}_{260}(9.6 \mu \mathrm{mol})$ of $\mathrm{p}-\mathrm{NH}_{2}-\mathrm{Ph}-$ $\mathrm{m}^{7} \mathrm{GpCH}_{2} \mathrm{pp}(\mathbf{1 1})$. The slurry was gently stirred overnight at $4^{\circ} \mathrm{C}$, after which the resin was filtered, washed with $50 \mathrm{~mL}$ of water, and suspended in $6 \mathrm{~mL}$ of $20 \%$ ethanol.

6-chloropurineriboside 5'-monophosphate, 6-CIAMP (12). Phosphorylation of 6-chloropurineriboside was performed as described previously (Jemielity et al. 2003) using Yoshikawa reaction (Yoshikawa et al. 1967). 6-chloropurineriboside (515 mg, $1.8 \mathrm{mmol}$ ) was suspended in $12 \mathrm{~mL}$ of trimethyl phosphate and cooled to $0^{\circ} \mathrm{C}$. Freshly distilled $\mathrm{POCl}_{3}(670 \mu \mathrm{L}, 1.12 \mathrm{~g}, 7.3 \mathrm{mmol})$ was added to the stirred mixture and stirring was continued for $\sim 2 \mathrm{~h}$, at which time the HPLC analysis showed the reaction was completed. Reaction was stopped by addition of $0.7 \mathrm{M} \mathrm{TEAB}$ to $\mathrm{pH}$ 7. The product was purified by ion-exchange chromatography on DEAE-Sephadex in linear $0-0.7 \mathrm{M}$ gradient of TEAB; 12 was obtained as TEA salt to yield $12,760 \mathrm{mODU}_{260}(1.31 \mathrm{mmol}, 72 \%)$. Analytical RP HPLC (gradient 1) $\mathrm{R}_{\mathrm{t}}=9.5 \mathrm{~min}$.

N6-(6-aminohexyl)adenosine 5' -monophosphate, $\mathrm{pA}^{\mathrm{N} 6 \mathrm{H}(\mathrm{CH} 2) 6 \mathrm{NH} 2}$ (13). Synthesis of $\mathbf{1 3}$ was performed as previously described (Huang et al. 2003). 6-ClAMP (12760 $\mathrm{mODU}_{260}$ (1.3 mmol) was suspended in $18 \mathrm{~mL}$ of water and treated with 1,6-diaminohexane (2.5 g, $19.3 \mathrm{mmol})$. Reaction was stirred for $1.5 \mathrm{~h}$ at room temperature until it was completed (assigned by analytical HPLC), after which it was stopped by neutralization with $10 \% \mathrm{HCl}$. The product was purified by ion-exchange chromatography on DEAESephadex in a linear $0-0.7 \mathrm{M}$ gradient of TEAB to yield 18,500 $\mathrm{mODU}_{260}(1.23 \mathrm{mmol}, 95 \%)$. HPLC (gradient 1) $\mathrm{R}_{\mathrm{t}}=14.2 \mathrm{~min}$. ESI MS (-) $m / z 445.2$ (calc. for $\mathrm{C}_{16} \mathrm{H}_{26} \mathrm{~N}_{6} \mathrm{O}_{7} \mathrm{P}: 445.2$ ).

N6-(6-aminohexyl)adenosine 5'-monophosphate P-imidazolide, $\mathrm{Im}-\mathrm{pA}^{\mathrm{N} 6 \mathrm{H}(\mathrm{CH} 2) 6 \mathrm{NH} 2}$ (14). Imidazole derivative of 13 was 
synthesized following the procedure used for compound $\mathbf{6}$ with several modifications. A total of $35 \mathrm{mg}$ of $14(0.068 \mathrm{mmol}$, yield $68 \%)$ was obtained from $\mathrm{pA}^{\mathrm{N} 6 \mathrm{H}(\mathrm{CH} 2) 6 \mathrm{NH} 2}(55 \mathrm{mg}, 0.1 \mathrm{mmol})$, imidazole (68 mg, $1 \mathrm{mmol}$ ), 2,2'-dithiodipyridine ( $66 \mathrm{mg}, 0.3 \mathrm{mmol}$ ), triethylamine $(28 \mu \mathrm{L}, 0.2 \mathrm{mmol})$, and triphenylphosphine $(78 \mathrm{mg}, 0.3$ mmol) mixed in anhydrous DMF $(2 \mathrm{~mL})$ and stirred for $24 \mathrm{~h}$. Analytical RP HPLC (gradient 1) $\mathrm{R}_{\mathrm{t}}=18.7 \mathrm{~min}$. ESI MS (-) $\mathrm{m} / z 495.2$ (calc. for $\mathrm{C}_{19} \mathrm{H}_{28} \mathrm{~N}_{8} \mathrm{O}_{6} \mathrm{P}: 495.2$ ).

P1-(7-methylguanosin-5'-yl) 1,2-methylenediphosphate, $\mathrm{m}^{7} \mathrm{GpCH}_{2} \mathrm{p}$ (15). Methylation of $\mathrm{GpCH}_{2} \mathrm{p}$ (5) was performed similarly as for $\mathrm{GpCH}_{2} \mathrm{pp}$ (7). $\mathrm{GpCH}_{2} \mathrm{p}$ (5) (12,650 $\mathrm{mODU}_{260}$, $1.05 \mathrm{mmol})$ was dissolved in DMSO $(27 \mathrm{~mL})$ and treated with $\mathrm{CH}_{3} \mathrm{I}(591 \mu \mathrm{L}, 1.35 \mathrm{~g}, 9.6 \mathrm{mmol})$. The mixture was stirred for $8 \mathrm{~h}$. 15 was obtained as triethylammonium salt after purification on DEAE-Sephadex in a linear 0-1.05 M TAEB gradient to yield 6460 $\mathrm{mODU}_{260}(0.57 \mathrm{mmol}, 54 \%)$. HPLC (gradient 1$) \mathrm{R}_{\mathrm{t}}=4.6 \mathrm{~min}$.

P1-(7-methylguanosin-5'-yl) diphosphate, $\mathrm{m}^{7} \mathrm{GDP}$ (16). $\mathrm{m}^{7} \mathrm{GDP}$ (16) was obtained using the same procedure. GDP $(12,700$ $\mathrm{mODU}_{260}, 1.06 \mathrm{mmol}$ ) was dissolved in DMSO $(27 \mathrm{~mL})$ and treated with $\mathrm{CH}_{3} \mathrm{I}(527 \mu \mathrm{L}, 1.2 \mathrm{~g}, 8.5 \mathrm{mmol})$. The mixture was stirred for $3 \mathrm{~h}$. 16 was purified on DEAE-Sephadex in a linear 0-1 M TAEB gradient to yield $5450 \mathrm{mODU}_{260}(0.48 \mathrm{mmol}$, $45 \%$ ). HPLC (gradient 1 ) $\mathrm{R}_{\mathrm{t}}=4.8 \mathrm{~min}$.

m7-guanosine 5'-diophosphate P2-imidazolide, Im- $\mathrm{m}^{7} \mathrm{GDP}$ (17). A total of $120 \mathrm{mg}$ of $\mathbf{1 7}$ was obtained from $\mathrm{m}^{7} \mathrm{GDP}$ (3000 $\mathrm{mODU}_{260}, 0.26 \mathrm{mmol}$ ), imidazole (270 mg, $3.98 \mathrm{mmol}$ ), 2,2' dithiodipyridine $(263 \mathrm{mg}, 1.19 \mathrm{mmol})$, triethylamine $(181 \mu \mathrm{L}$, $1.05 \mathrm{mmol}$ ), triphenylphosphine (208 $\mathrm{mg}, 0.79 \mathrm{mmol})$ mixed in $4 \mathrm{~mL}$ of DMF, and stirred for $3 \mathrm{~d}$ following the procedure described for compound 6. Analytical RP HPLC (gradient 1) $\mathrm{R}_{\mathrm{t}}=7.2 \mathrm{~min}$.

P1-(7-methylguanosin-5'-yl) P3-(N6-(6-aminohexyl)adenosin$5^{\prime}$-yl) triphosphate, $\mathrm{m}^{7} \mathrm{Gppp} \mathrm{A}^{\mathrm{N} 6 \mathrm{H}(\mathrm{CH} 2) 6 \mathrm{NH} 2}$ (18). Coupling of $\mathrm{m}^{7} \mathrm{GDP}-\mathrm{Im}(\mathbf{1 7})(55.1 \mathrm{mg}, 0.1 \mathrm{mmol})$ and $\mathrm{pA}^{\mathrm{N} 6 \mathrm{H}(\mathrm{CH} 2) 6 \mathrm{NH} 2}(\mathbf{1 3})$ (1500 $\mathrm{mODU}_{260}, 0.1 \mathrm{mmol}$ ) was performed following the procedure described for compound 7. Both nucleotides and $\mathrm{ZnCl}_{2}$ (109 $\mathrm{mg}, 0.8 \mathrm{mmol}$ ) were mixed in anhydrous DMF $(2 \mathrm{~mL})$ and stirred for $24 \mathrm{~h}$ (the reaction progress was monitored by HPLC). The product was isolated on DEAE-Sephadex using 0-1.1 M gradient of TEAB, and further purified using preparative HPLC. 18 was obtained as $\mathrm{NH}_{4}{ }^{+}$salt with a yield of $849 \mathrm{mODU}_{260}(0.036$ mmol, 36\%). HPLC (gradient 2) $\mathrm{R}_{\mathrm{t}}=9.2 \mathrm{~min}$. ESI MS (-) $\mathrm{m} / z 884.2$ (calc. for $\mathrm{C}_{27} \mathrm{H}_{41} \mathrm{~N}_{11} \mathrm{O}_{17} \mathrm{P}_{3}$ : 884.2). $\delta_{\mathrm{H}} 8.92\left(<1 \mathrm{H}, \mathrm{H} 8_{\mathrm{m} 7 \mathrm{G}}\right), 8.38(1 \mathrm{H}$, s, $\left.\mathrm{H} 2_{\mathrm{A}}\right) ; 8.13\left(1 \mathrm{H}, \mathrm{s}, \mathrm{H} 8_{\mathrm{A}}\right) ; 6.01\left(1 \mathrm{H}, \mathrm{d}, J_{1^{\prime}, 2^{\prime}} 6.2, \mathrm{H} 1^{\prime}{ }_{\mathrm{A}}\right) ; 5.86(1 \mathrm{H}, \mathrm{d}$, $\left.J_{1^{\prime}, 2^{\prime}} 3.5, \mathrm{H}^{\prime}{ }_{\mathrm{m} 7 \mathrm{G}}\right) ; 4.69\left(1 \mathrm{H}, \mathrm{dd}, J_{1^{\prime}, 2^{\prime}} 6.2, J_{2^{\prime}, 3^{\prime}} 5.0, \mathrm{H} 2^{\prime}{ }_{\mathrm{A}}\right) ; 4.50(2 \mathrm{H}$, $\left.\mathrm{m}, \mathrm{H} 2^{\prime}{ }_{\mathrm{m} 7 \mathrm{G}}, \mathrm{H} 3^{\prime}{ }_{\mathrm{A}}\right), 4.40\left(2 \mathrm{H}, \mathrm{m}, \mathrm{H} 3^{\prime}{ }_{\mathrm{m} 7 \mathrm{G}}, \mathrm{H}^{\prime}{ }_{\mathrm{A}}\right) ; 4.38\left(1 \mathrm{H}, \mathrm{m}, \mathrm{H} 5^{\prime}\right)$ $4.34\left(1 \mathrm{H}, \mathrm{m}, \mathrm{H} 4{ }^{\prime}{ }_{\mathrm{m} 7 \mathrm{G}}\right) ; 4.26\left(3 \mathrm{H}, \mathrm{m}, \mathrm{H} 5^{\prime \prime}{ }_{\mathrm{m} 7 \mathrm{G}}, \mathrm{H} 5^{\prime}{ }_{\mathrm{A}}, \mathrm{H} 5^{\prime \prime}{ }_{\mathrm{A}}\right) ; 3.98$ $\left(3 \mathrm{H}, \mathrm{s},-\mathrm{CH}_{3}\right) ; 3.49\left(2 \mathrm{H}, \mathrm{bs},-\mathrm{NHCH}_{2}\right) ; 2.96\left(2 \mathrm{H}, \mathrm{t}, J 7.6, \underline{\mathbf{C H}}_{2} \mathrm{NH}_{2}\right)$; $1.65\left(4 \mathrm{H}, \mathrm{m}, \mathrm{NHCH}_{2} \mathrm{CH}_{2}(\mathrm{CH} 2)_{2} \mathrm{CH}_{2} \mathrm{CH}_{2} \mathrm{NH}_{2}\right) ; 1.41(4 \mathrm{H}, \mathrm{m}$, $\left.\mathrm{NHCH}_{2} \mathrm{CH}_{2}(\mathbf{C H} 2)_{2} \mathrm{CH}_{2} \mathrm{CH}_{2} \mathrm{NH}_{2}\right) . \delta_{\mathrm{P}}-11.25$ (2P, m, $\left.\mathrm{P}_{\alpha}, \mathrm{P}_{\gamma}\right)$, $-22.74\left(1 \mathrm{P}, \mathrm{t}, J_{\alpha, \beta}=J_{\beta, \gamma} 18.5, \mathrm{P}_{\beta}\right)$.

P1-(7-methylguanosin-5'-yl) P3-(N6-(6-aminohexyl)adenosin-5'-yl) 1,2-methylenetriphosphate, $m^{7} \mathrm{GpCH}_{2} \mathrm{ppA}^{\mathrm{N} 6 \mathrm{H}(\mathrm{CH} 2) 6 \mathrm{NH} 2}$ (19). Synthesis of 19 was obtained in similar way. Im-pA $\mathrm{N}^{\mathrm{N} 6 \mathrm{H}(\mathrm{CH} 2) 6 \mathrm{NH} 2}$ (14) (35 $\mathrm{mg}, \sim 0.04 \mathrm{mmol}$ regarding contamination), $\mathrm{m}^{7} \mathrm{GpCH}_{2} \mathrm{p}$ (15) (500 mODU ${ }_{260}, 0.045 \mathrm{mmol}$ ) and $\mathrm{ZnCl}_{2}(95 \mathrm{mg}, 0.7 \mathrm{mmol}$ ) were mixed in anhydrous DMF $(2 \mathrm{~mL})$ and stirred for $24 \mathrm{~h}$. Obtained product 19 was purified on DEAE-Sephadex in a linear 0-1 M TAEB gradient and further purified using preparative HPLC to yield 896 $\operatorname{mODU}_{260}(0.017 \mathrm{mmol}, 42 \%)$. HPLC (gradient 1$) \mathrm{R}_{\mathrm{t}}=14.4 \mathrm{~min}$. ESI MS (-) $m / z 882.2$ (calc. for $\mathrm{C}_{28} \mathrm{H}_{43} \mathrm{~N}_{11} \mathrm{O}_{16} \mathrm{P}_{3}: 882.2$ ). $\delta_{\mathrm{H}} 8.41$ $\left(1 \mathrm{H}, \mathrm{s}, \mathrm{H} 2_{\mathrm{A}}\right) ; 8.17\left(1 \mathrm{H}, \mathrm{s}, \mathrm{H} 8_{\mathrm{A}}\right) ; 6.04\left(1 \mathrm{H}, \mathrm{m}, J_{1^{\prime}, 2^{\prime}} 5.5, \mathrm{H}^{\prime}{ }_{\mathrm{A}}\right) ; 5.91$ $\left(1 \mathrm{H}, \mathrm{m}, J_{1^{\prime}, 2^{\prime}} 3.7, \mathrm{H} 1^{\prime}{ }_{\mathrm{m} 7 \mathrm{G}}\right) ; 4.67\left(1 \mathrm{H}, \mathrm{dd}, J_{1^{\prime}, 2^{\prime}} 5.5, J_{2^{\prime}, 3^{\prime}} 4.5, \mathrm{H} 2^{\prime}{ }_{\mathrm{A}}\right)$; $4.58\left(1 \mathrm{H}, \mathrm{m}, \mathrm{H} 2^{\prime}{ }_{\mathrm{m} 7 \mathrm{G}}\right) ; 4.48\left(2 \mathrm{H}, \mathrm{m}, \mathrm{H}^{\prime}{ }^{\prime}{ }_{\mathrm{m} 7 \mathrm{G}}, \mathrm{H}^{\prime}{ }_{\mathrm{A}}\right) ; 4.38-4.21(6 \mathrm{H}, \mathrm{m}$, $\left.\mathrm{H} 4{ }_{\mathrm{A}} \mathrm{H} 4{ }_{\mathrm{m} 7 \mathrm{G}}, \mathrm{H} 5{ }_{\mathrm{m} 7 \mathrm{G}} \mathrm{H} 5{ }^{\prime}{ }_{\mathrm{A}}, \mathrm{H} 5^{\prime \prime}{ }_{\mathrm{A}}, \mathrm{H} 5{ }^{\prime \prime}{ }_{\mathrm{m} 7 \mathrm{G}}\right) ; 4.02(3 \mathrm{H}, \mathrm{s}$, $\left.\mathrm{CH}_{3}\right) ; 3.53\left(2 \mathrm{H}\right.$, bs, $\left.-\mathrm{NH}_{\underline{\mathrm{CH}}}\right) ; 2.96\left(2 \mathrm{H}, \mathrm{m}, \underline{\mathrm{CH}}{ }_{2} \mathrm{NH}_{2}\right)$; $2.39\left(2 \mathrm{H}, \mathrm{m}, J_{\mathrm{P} \beta,-\mathrm{CH} 2-}=J_{\mathrm{P} \gamma,-\mathrm{CH}_{2}-} 20.2, \mathrm{p}-\underline{\mathrm{CH}}_{2}-\mathrm{p}\right) ; 1.66$ $\left(4 \mathrm{H}, \quad \mathrm{m}, \quad \mathrm{NHCH}_{2} \underline{\mathrm{CH}}_{2}\left(\mathrm{CH}_{2}\right)_{2} \underline{\mathbf{C H}}_{2} \mathrm{CH}_{2} \mathrm{NH}_{2}\right) ; 1.42(4 \mathrm{H}, \mathrm{m}$, $\left.\mathrm{NHCH}_{2} \mathrm{CH}_{2}\left(\mathrm{CH}_{2}\right)_{2} \mathrm{CH}_{2} \mathrm{CH}_{2} \mathrm{NH}_{2}\right) . \delta_{\mathrm{P}} 17.60\left(1 \mathrm{P}, \mathrm{m}, \mathrm{P}_{\gamma}\right) ; 7.46$ $\left(1 \mathrm{P}, \mathrm{m}, \mathrm{P}_{\beta}\right) ;-10.74\left(1 \mathrm{P}, \mathrm{d}, J_{\alpha, \beta} 23.3, \mathrm{P}_{\alpha}\right)$.

P1-(7-methylguanosin-5'-yl) P3-adenosine-5'-yl triphosphate, $\mathrm{m}^{7}$ GpppA-Sepharose (3). A total of $6 \mathrm{~mL}$ (settled volume) of resin 3 was obtained from $155 \mathrm{mODU}_{260}(6.27 \mu \mathrm{mol})$ of $\mathrm{m}^{7}$ $\mathrm{GpppA}^{\mathrm{N} 6 \mathrm{H}(\mathrm{CH} 2) 6 \mathrm{NH} 2}$ (18), following the procedure described for compound 2.

P1-(7-methylguanosin-5'-yl) P3-adenosine-5'-yl 1,2-methylenetriphosphate, $\mathrm{m}^{7} \mathrm{GpCH} \mathrm{H}_{2} \mathrm{ppA}$-Sepharose (4). Similarly, 6.5 $\mathrm{mL}$ (settled volume) of resin 4 was obtained from $164 \mathrm{mODU}_{260}$ $(6.9 \mu \mathrm{mol})$ of $\mathrm{m}^{7} \mathrm{GpCH}_{2} \mathrm{ppA}^{\mathrm{N} 6 \mathrm{H}(\mathrm{CH} 2) 6 \mathrm{NH} 2}$ (19).

\section{Biological assays}

Used reagents were purchased from Sigma-Aldrich unless otherwise stated.

\section{Determination of degrees of substitution (DS)}

A total of $250 \mu \mathrm{L}$ of resin (settled volume) was suspended in $1 \mathrm{~mL}$ of buffer $\mathrm{P}\left(75 \mathrm{mM}\right.$ Tris- $\mathrm{HCl}$ at $\left.\mathrm{pH} 8.8,5 \mathrm{mM} \mathrm{MgCl}_{2}\right)$ and treated with Alkaline phosphatase ( $4 \mathrm{U}, \mathrm{TaKaRa})$ and phosphodiesterase I (5 U, Pharmacia Biotech) (Webb et al. 1984). The change in absorbance of the supernatant fluid was followed at $260 \mathrm{~nm}$. The absorbance value obtained after $4 \mathrm{~h}$ of incubation was used for calculation of DS after subtraction of value measured for a negative control (unmodified Sepharose 4B, GE Healthcare). Each reaction was performed in three replicas.

\section{Expression and purification of recombinant proteins}

Mouse eukaryotic initiation factor eIF4E (residues 28-217) was expressed in E. coli BL21(DE3) as inclusion bodies. The guanidinium-solubilized protein was renatured by one-step dialysis and purified by ion-exchange chromatography on a HiTrapSP column without contact with cap analogs (Marcotrigiano et al. 1997). The concentration of eIF4E was determined spectrophotometrically assuming $\varepsilon_{280}=53,400 \mathrm{M}^{-1} \mathrm{~cm}^{-1}$. Human DcpS was expressed in E. coli Rosetta DE3 according to the procedures described previously (Cohen et al. 2004) with several modifications. Histagged DcpS was purified by a two-step procedure on Ni-NTA Syperflow Cartridge (QIAGEN) followed by gel filtration on Superdex 200 column (GE Healthcare) using the AKTA Purifier system (GE Healthcare). The concentration of DcpS was determined spectrophotometrically assuming $\varepsilon_{280}=$ $30,495 \mathrm{M}^{-1} \mathrm{~cm}^{-1}$. 


\section{Binding affinities for elF4E}

Fluorescence titration measurements were carried using a LS-55 spectrofluorometer (Perkin Elmer Co.) in $50 \mathrm{mM} \mathrm{HEPES} / \mathrm{KOH}$ (pH 7.2), $100 \mathrm{mM} \mathrm{KCl}, 0.5 \mathrm{mM}$ EDTA, $1 \mathrm{mM}$ DTT at $20.0 \pm$ $0.2^{\circ} \mathrm{C}$. Aliquots of $1 \mu \mathrm{L}$ of solutions with increasing concentration of cap analog were added to $1.4 \mathrm{~mL}$ of $0.1-\mu \mathrm{M}$ protein solutions. Fluorescence intensities (excitation at $280 \mathrm{~nm}$ with $2.5 \mathrm{~nm}$ bandwidth and detection at $337 \mathrm{~nm}$ with $4 \mathrm{~nm}$ bandwidth and $290 \mathrm{~nm}$ cut-off filter) were corrected for sample dilution and the inner filter effect. Equilibrium association constants $\left(K_{\mathrm{AS}}\right)$ were determined by fitting the theoretical dependence of the fluorescence intensity on the total concentration of cap analog to the experimental data points according to the equation described previously (Niedzwiecka et al. 2002). The concentration of protein was fitted as a free parameter of equilibrium equation showing the amount of "active" protein. The final $K_{\mathrm{AS}}$ was calculated as a weighted average of three to five independent titrations, with the weights taken as the reciprocals of the numerical standard deviations squared. Numerical nonlinear least-squares regression analysis was performed using ORIGIN 6.0 (Microcal Software, Inc.).

\section{Yeast extract preparation}

Wild-type yeast strains BY4741 and CBP20-Myc (Wong et al. 2007) were grown at $30^{\circ} \mathrm{C}$ in $2 \mathrm{~L}$ of YPD medium $(20 \mathrm{~g} / \mathrm{L}$ Bacto Tryptone, Difco; 10 g/L Bacto Yeast Extract, Difco; 2\% D-glucose, $50 \mu \mathrm{g} / \mathrm{mL}$ Ampicilin) to $1-2 \mathrm{OD}_{600}$. Strain Y258 expressing eIF4E$\mathrm{His}_{6} / \mathrm{HA} / \mathrm{ZZ}$ under the control of the $\mathrm{P}_{G A L}$ promoter from a plasmid BG1805 (Open Biosystems) (Gelperin et al. 2005) was grown in $1.3 \mathrm{~L}$ of complete synthetic medium without uracil $(0.77$ g/L CSM-URA, MP; 6.7 g/L YNB without amino acids, Difco, 2\% sodium-L- lactate, $50 \mu \mathrm{g} / \mathrm{mL}$ Ampicilin) at $30^{\circ} \mathrm{C}$ to $0.5-1 \mathrm{OD}_{600}$. Induction with $650 \mathrm{~mL}$ of $3 \times$ induction medium $(60 \mathrm{~g} / \mathrm{L}$ Bacto Tryptone, Difco; $30 \mathrm{~g} / \mathrm{L}$ Bacto Yeast Extract, Difco; $6 \%$ D-galactose, $50 \mu \mathrm{g} / \mathrm{mL}$ Ampicilin) was carried out for $6 \mathrm{~h}$ at $30^{\circ} \mathrm{C}$. Cells were harvested, resuspended in an equal volume of lysis buffer (40 mM Hepes at $\mathrm{pH} 8.0,250 \mathrm{mM} \mathrm{NaCl}, 1 \mathrm{mM}$ DTT), frozen in liquid nitrogen, and homogenized in a laboratory blender (Waring) with dry ice $(4 \times 2 \mathrm{~min})$. The lysate was then centrifuged for $20 \mathrm{~min}$ at $50,000 \mathrm{~g}$ at $4^{\circ} \mathrm{C}$. The extract was cleared by ultracentrifugation at $120,000 \mathrm{~g}$ for $1 \mathrm{~h}, 30 \mathrm{~min}$ at $4^{\circ} \mathrm{C}$, and dialyzed for $4 \mathrm{~h}$ at $4^{\circ} \mathrm{C}$ in buffer $\mathrm{D}(40 \mathrm{mM}$ Hepes at $\mathrm{pH} 8.0,150$ $\mathrm{mM} \mathrm{NaCl}, 1 \mathrm{mM}$ DTT, $1 \mathrm{mM}$ PMSF, 20\% glycerol).

\section{Large-scale purification of yeast cap-binding proteins}

Yeast extract prepared from BY4741 and CBP20-Myc cells was supplemented with reduced triton X100 (0.1\% final concentration) and GTP (100 $\mu \mathrm{M}$ final concentration). A total of $7-10 \mathrm{~mL}$ of extract was incubated for $3 \mathrm{~h}$ at $4^{\circ} \mathrm{C}$ with slow rotation with 200 $\mu \mathrm{L}$ (settled volume) of resins (1-4) or control GTP-Sepharose and unmodified $\mathrm{CNBr}$ activated Sepharose 4B (GE Healthcare), prewashed in IPP150 buffer $(10 \mathrm{mM}$ Tris- $\mathrm{HCl}$ at $\mathrm{pH} 8.0,150$ $\mathrm{mM} \mathrm{NaCl}, 0.1 \%$ rTX100). Flow-through fractions were then separated by centrifugation $\left(5 \mathrm{~min}\right.$ at $400 \mathrm{~g}$, at $4^{\circ} \mathrm{C}$ ). The resins were resuspended in $10 \mathrm{~mL}$ of buffer IPP150 with $100 \mu \mathrm{M}$ GTP and washed twice with $10 \mathrm{~mL}$ of buffer IPP150/100 $\mu \mathrm{M}$ GTP and twice with $10 \mathrm{~mL}$ of buffer B (10 mM Tris- $\mathrm{HCl}$ at $\mathrm{pH} 8.0,150 \mathrm{mM}$
$\mathrm{NaCl})$ in polyprep chromatography columns (10 mL, BioRad). Bound proteins were eluted with buffer $\mathrm{E}(10 \mathrm{mM}$ Tris- $\mathrm{HCl}$ at $\mathrm{pH}$ $8.0,150 \mathrm{mM} \mathrm{NaCl}, 0.1-1 \mathrm{mM} \mathrm{m}^{7} \mathrm{GTP} ; 6 \times 200 \mu \mathrm{L}$ ) by incubation with the resin for $10 \mathrm{~min}$ at $4^{\circ} \mathrm{C}$. The experiments were repeated two to three times.

\section{Protein precipitation and analysis by mass spectrometry}

Proteins from combined eluates were precipitated using pyrogallol red (Aguilar et al. 1999) prior to further analysis. For mass spectrometry analysis, proteins were separated by electrophoresis performed on NuPAGE 4\%-12\% gradient gels using MES buffer gel system (Invitrogen) and stained with SimplyBlue SafeStain (Invitrogen). Mass spectrometry was performed on proteins purified from wild-type strain (BY4741) both with eluates in solution and from bands excised from gels. Samples were processed by standard procedures with trypsin digestion and cysteine alkylation. The obtained peptide mixtures were separated on a nanoHPLC system and the column outlet was coupled to the ion source of an LTQ FTICR spectrometer (Brooks et al. 2010).

\section{Small-scale purification of cap-binding proteins}

Yeast extract (containing eIF4E-His ${ }_{6} / \mathrm{HA} / \mathrm{ZZ}$ ) or protein samples $(520 \mu \mathrm{g} / \mathrm{mL}$ eIF4E and $200 \mu \mathrm{g} / \mathrm{mL}$ DcpS) were supplemented with reduced triton X100 ( $0.1 \%$ final concentration) and GTP (100 $\mu \mathrm{M}$ final concentration). A total of $300-500 \mu \mathrm{L}$ of extract or protein sample was incubated for $2 \mathrm{~h}$ with $50 \mu \mathrm{L}$ (settled volume) of resin (1-4) equilibrated with IPP150 buffer in $4^{\circ} \mathrm{C}$. Flowthrough fractions were separated and the resins were washed twice with $0.5 \mathrm{~mL}$ of buffer IPP150/100 $\mu \mathrm{M}$ GTP and three times with $0.5 \mathrm{~mL}$ of buffer B. Bound proteins were eluted with buffer E2 (10 $\mathrm{mM}$ Tris- $\mathrm{HCl}$ at $\mathrm{pH} 8.0,150 \mathrm{mM} \mathrm{NaCl}, 1 \mathrm{mM} \mathrm{m}^{7} \mathrm{GTP} ; 4 \times 40$ $\mu \mathrm{L})$ by incubation with the resin for $5 \mathrm{~min}$. The purification procedure was carried out in $0.8-\mathrm{mL}$ spin columns (Mo Bi Tec). The experiments were repeated two to three times.

\section{Western blot analysis}

Western blot analysis was carried out with horseradish peroxidase-anti-peroxidase (PAP, Sigma) in a 1:2000 dilution, mouse anti-Myc antibody (Santa Cruz Biotechnology) in a 1:5000 dilution, and horseradish peroxidase-conjugated anti-mouse antibody (Calbiochem) in a 1:10000 dilution. Visualization was performed using a CCD-camera (Fluorchem SP, Gel Biosciences).

\section{SUPPLEMENTAL MATERIAL}

Supplemental material is available for this article, showing the list of all proteins bound to $\mathrm{m}^{7} \mathrm{GTP}-, \mathrm{m}^{7} \mathrm{GpppA}-, \mathrm{m}^{7} \mathrm{GpCH}_{2} \mathrm{ppA}-$, GTP-, and 4B-Sepharoses identified by tandem mass spectrometry.

\section{ACKNOWLEDGMENTS}

We thank Mike Kiledjian (Rutgers University) for providing the hDcpS encoding plasmid; Zbigniew M. Darzynkiewicz (Institute of Experimental Physics, University of Warsaw), and Krystian Stodus (Institute of Biochemistry and Biophysics of the Polish Academy of Sciences, IBB PAS, Warsaw) for expressing and purifying the protein; Alan Hinnebusch (National Institute of 
Child Health and Human Development) for providing the CBP20-Myc strain; Andrzej Dziembowski (Institute of Biochemistry and Biophysics of the Polish Academy of Sciences, IBB PAS, Warsaw) for discussions; the Laboratory of Biological NMR (IBB PAS, Warsaw) for access to the NMR apparatus, and the Laboratory of Mass Spectrometry (IBB PAS, Warsaw) for recording MS spectra. This work was supported by grants from the Polish Ministry of Science and Higher Education to J.J. and E.D. (N N204 089438 and N N301 096339), the Howard Hughes Medical Institute to E.D. (55005 604), the Wellcome Trust to J.K. (067504/ Z/02/Z), the European Social Fund (UDA-POKL.04.01.01-00-072/ 09-00), by the EU through the European Social Fund (contract number UDA-POKL.04.01.01-00-072/09-00) and the Ministry of Science and Higher Education intramural BW through the Faculty of Biology, University of Warsaw to S.A.S.

Received December 22, 2011; accepted April 12, 2012.

\section{REFERENCES}

Aguilar RM, Bustamante JJ, Hernandez PG, Martinez AO, Haro LS. 1999. Precipitation of dilute chromatographic samples $(\mathrm{ng} / \mathrm{ml})$ containing interfering substances for SDS-PAGE. Anal Biochem 267: 344-350.

Altmann M, Edery I, Sonenberg N, Trachsel H. 1985. Purification and characterization of protein synthesis initiation factor eIF-4E from the yeast Saccharomyces cerevisiae. Biochemistry 24: 60856089.

Bail S, Kiledjian M. 2008. DcpS, a general modulator of cap-binding protein-dependent processes? RNA Biol 5: 216-219.

Baron-Benhamou J, Fortes P, Inada T, Preiss T, Hentze MW. 2003. The interaction of the cap-binding complex (CBC) with eIF4G is dispensable for translation in yeast. RNA 9: 654-662.

Berglund O, Eckstein F. 1972. Synthesis of ATP- and dATPsubstituted Sepharoses and their application in the purification of phage-T4-induced ribonucleotide reductase. Eur J Biochem 28: $492-496$.

Blanc A, Goyer C, Sonenberg N. 1992. The coat protein of the yeast double-stranded RNA virus L-A attaches covalently to the cap structure of eukaryotic mRNA. Mol Cell Biol 12: 3390-3398.

Brooks MA, Gewartowski K, Mitsiki E, Letoquart J, Pache RA, Billier Y, Bertero M, Correa M, Czarnocki-Cieciura M, Dadlez M, et al. 2010. Systematic bioinformatics and experimental validation of yeast complexes reduces the rate of attrition during structural investigations. Structure 18: 1075-1082.

Browning KS, Maia DM, Lax SR, Ravel JM. 1987. Identification of a new protein synthesis initiation factor from wheat germ. J Biol Chem 262: 538-541.

Calero G, Wilson KF, Ly T, Rios-Steiner JL, Clardy JC, Cerione RA. 2002. Structural basis of $\mathrm{m}^{7} \mathrm{GpppG}$ binding to the nuclear capbinding protein complex. Nat Struct Biol 9: 912-917.

Cohen LS, Mikhli C, Friedman C, Jankowska-Anyszka M, Stepinski J, Darzynkiewicz E, Davis RE. 2004. Nematode $\mathrm{m}^{7} \mathrm{GpppG}$ and $\mathrm{m}_{3}^{2,2,7}$ GpppG decapping: Activities in Ascaris embryos and characterization of $C$. elegans scavenger DcpS. RNA 10: 1609-1624.

Cosentino GP, Schmelzle T, Haghighat A, Helliwell SB, Hall MN, Sonenberg N. 2000. Eaplp, a novel eukaryotic translation initiation factor 4E-associated protein in Saccharomyces cerevisiae. Mol Cell Biol 20: 4604-4613.

Cuatrecasas P, Wilchek M, Anfinsen CB. 1968. Selective enzyme purification by affinity chromatography. Proc Natl Acad Sci 61: 636-643.

Darzynkiewicz E, Ekiel I, Tahara SM, Seliger LS, Shatkin AJ. 1985. Chemical synthesis and characterization of 7-methylguanosine cap analogs. Biochemistry 24: 1701-1707.
Edery I, Altmann M, Sonenberg N. 1988. High-level synthesis in Escherichia coli of functional cap-binding eukaryotic initiation factor eIF-4E and affinity purification using a simplified capanalog resin. Gene 74: 517-525.

Flaherty SM, Fortes P, Izaurralde E, Mattaj IW, Gilmartin GM. 1997. Participation of the nuclear cap binding complex in pre-mRNA $3^{\prime}$ processing. Proc Natl Acad Sci 94: 11893-11898.

Gelperin DM, White MA, Wilkinson ML, Kon Y, Kung LA, Wise KJ, Lopez-Hoyo N, Jiang L, Piccirillo S, Yu H, et al. 2005. Biochemical and genetic analysis of the yeast proteome with a movable ORF collection. Genes Dev 19: 2816-2826.

Gu M, Fabrega C, Liu SW, Liu H, Kiledjian M, Lima CD. 2004. Insights into the structure, mechanism, and regulation of scavenger mRNA decapping activity. Mol Cell 14: 67-80.

Huang F, Wang G, Coleman T, Li N. 2003. Synthesis of adenosine derivatives as transcription initiators and preparation of $5^{\prime}$ fluorescein- and biotin-labeled RNA through one-step in vitro transcription. RNA 9: 1562-1570.

Izaurralde E, Lewis J, McGuigan C, Jankowska M, Darzynkiewicz E, Mattaj IW. 1994. A nuclear cap binding protein complex involved in pre-mRNA splicing. Cell 78: 657-668.

Jankowska-Anyszka M, Piecyk K. 2011. Dinucleotide cap analogue affinity resins for purification of proteins that specifically recognize the 5' end of mRNA. Bioorg Med Chem Lett 21: 61316134.

Jankowska-Anyszka M, Lamphear BJ, Aamodt EJ, Harrington T, Darzynkiewicz E, Stolarski R, Rhoads RE. 1998. Multiple isoforms of eukaryotic protein synthesis initiation factor $4 \mathrm{E}$ in Caenorhabditis elegans can distinguish between mono- and trimethylated mRNA cap structures. J Biol Chem 273: 10538-10542.

Jemielity J, Fowler T, Zuberek J, Stepinski J, Lewdorowicz M, Niedzwiecka A, Stolarski R, Darzynkiewicz E, Rhoads RE. 2003. Novel "anti-reverse" cap analogs with superior translational properties. RNA 9: 1108-1122.

Kadokura M, Wada T, Urashima C, Sekine M. 1997. Efficient synthesis of $\gamma$-methyl-capped guanosine $5^{\prime}$-triphosphate as a $5^{\prime}$ terminal unique structure of U6 RNA via a new triphosphate bond formation involving activation of methyl phosphorimidazolidate using $\mathrm{ZnCl}_{2}$ as a catalyst in DMF under anhydrous conditions. Tetrahedron Lett 38: 8359-8362.

Kalek M, Jemielity J, Grudzien E, Zuberek J, Bojarska E, Cohen LS, Stepinski J, Stolarski R, Davis RE, Rhoads RE, et al. 2005a. Synthesis and biochemical properties of novel mRNA 5' cap analogs resistant to enzymatic hydrolysis. Nucleosides Nucleotides Nucleic Acids 24: 615-621.

Kalek M, Jemielity J, Stepinski J, Stolarski R, Darzynkiewicz E. 2005b. A direct method for the synthesis of nucleoside $5^{\prime}$-methylenebis (phosphonate)s from nucleosides. Tetrahedron Lett 46: 24172421.

Kalek M, Jemielity J, Darzynkiewicz ZM, Bojarska E, Stepinski J, Stolarski R, Davis RE, Darzynkiewicz E. 2006. Enzymatically stable 5' mRNA cap analogs: synthesis and binding studies with human DcpS decapping enzyme. Bioorg Med Chem 14: 3223-3230.

Kiraga-Motoszko K, Stepinski J, Niedzwiecka A, Jemielity J, WszelakaRylik M, Stolarski R, Zielenkiewicz W, Darzynkiewicz E. 2003. Interaction between yeast eukaryotic initiation factor eIF4E and mRNA 5' cap analogues differs from that for murine eIF4E. Nucleosides Nucleotides Nucleic Acids 22: 1711-1714.

Kiriakidou M, Tan GS, Lamprinaki S, De Planell-Saguer M, Nelson PT, Mourelatos Z. 2007. An mRNA $\mathrm{m}^{7} \mathrm{G}$ cap binding-like motif within human Ago2 represses translation. Cell 129: 1141-1151.

Knorre DG, Kurbatov VA, Samukov VV. 1976. General method for the synthesis of ATP $\gamma$-derivatives. FEBS Lett 70: 105-108.

Lewis JD, Izaurralde E. 1997. The role of the cap structure in RNA processing and nuclear export. Eur J Biochem 247: 461-469.

Liu H, Kiledjian M. 2005. Scavenger decapping activity facilitates $5^{\prime}$ to 3' mRNA decay. Mol Cell Biol 25: 9764-9772.

Liu H, Kiledjian M. 2006. Decapping the message: a beginning or an end. Biochem Soc Trans 34: 35-38. 
Liu H, Rodgers ND, Jiao X, Kiledjian M. 2002. The scavenger mRNA decapping enzyme DcpS is a member of the HIT family of pyrophosphatases. EMBO J 21: 4699-4708.

Lowe CR, Mosbach K, Dean PD. 1972. Some applications of insolubilised cofactors to the purification of pyridine nucleotidedependent dehydrogenases. Biochem Biophys Res Commun 48: 1004-1010.

Marcotrigiano J, Gingras AC, Sonenberg N, Burley SK. 1997. Cocrystal structure of the messenger RNA $5^{\prime}$ cap-binding protein (eIF4E) bound to 7-methyl-GDP. Cell 89: 951-961.

Matera AG, Terns RM, Terns MP. 2007. Non-coding RNAs: lessons from the small nuclear and small nucleolar RNAs. Nat Rev Mol Cell Biol 8: 209-220.

Mazza C, Segref A, Mattaj IW, Cusack S. 2002a. Co-crystallization of the human nuclear cap-binding complex with a $\mathrm{m}^{7} \mathrm{GpppG}$ cap analogue using protein engineering. Acta Crystallogr D Biol Crystallogr 58: 2194-2197.

Mazza C, Segref A, Mattaj IW, Cusack S. 2002b. Large-scale induced fit recognition of an $\mathrm{m}^{7} \mathrm{GpppG}$ cap analogue by the human nuclear cap-binding complex. EMBO J 21: 5548-5557.

McKendrick L, Thompson E, Ferreira J, Morley SJ, Lewis JD. 2001. Interaction of eukaryotic translation initiation factor $4 \mathrm{G}$ with the nuclear cap-binding complex provides a link between nuclear and cytoplasmic functions of the $\mathrm{m}^{7}$ Guanosine cap. Mol Cell Biol 21: 3632-3641.

Mukaiyama T, Hashimoto M. 1972. Synthesis of oligothymidylates and nucleoside cyclic phosphates by oxidation-reduction condensation. J Am Chem Soc 94: 8528-8532.

Niedzwiecka A, Marcotrigiano J, Stepinski J, Jankowska-Anyszka M, Wyslouch-Cieszynska A, Dadlez M, Gingras AC, Mak P, Darzynkiewicz E, Sonenberg N, et al. 2002. Biophysical studies of eIF4E cap-binding protein: recognition of mRNA $5^{\prime}$ cap structure and synthetic fragments of eIF4G and 4E-BP1 proteins. J Mol Biol 319: 615-635.

Nojima T, Hirose T, Kimura H, Hagiwara M. 2007. The interaction between cap-binding complex and RNA export factor is required for intronless mRNA export. J Biol Chem 282: 1564515651.

Pabis M, Neufeld N, Shav-Tal Y, Neugebauer KM. 2010. Binding properties and dynamic localization of an alternative isoform of the cap-binding complex subunit CBP20. Nucleus 1: 412-421.

Ptushkina M, Fierro-Monti I, van den Heuvel J, Vasilescu S, Birkenhager R, Mita K, McCarthy JE. 1996. Schizosaccharomyces pombe has a novel eukaryotic initiation factor $4 \mathrm{~F}$ complex containing a cap-binding protein with the human eIF4E C-terminal motif KSGST. J Biol Chem 271: 32818-32824.

Ramirez CV, Vilela C, Berthelot K, McCarthy JE. 2002. Modulation of eukaryotic mRNA stability via the cap-binding translation complex eIF4F. J Mol Biol 318: 951-962.

Richter JD, Sonenberg N. 2005. Regulation of cap-dependent translation by eIF4E inhibitory proteins. Nature 433: 477480 .

Ruud KA, Kuhlow C, Goss DJ, Browning KS. 1998. Identification and characterization of a novel cap-binding protein from Arabidopsis thaliana. J Biol Chem 273: 10325-10330.

Rydzik AM, Lukaszewicz M, Zuberek J, Kowalska J, Darzynkiewicz ZM, Darzynkiewicz E, Jemielity J. 2009. Synthetic dinucleotide mRNA cap analogs with tetraphosphate $5^{\prime}, 5^{\prime}$ bridge containing methylenebis(phosphonate) modification. Org Biomol Chem 7: 4763-4776.

Salehi Z, Geffers L, Vilela C, Birkenhager R, Ptushkina M, Berthelot K, Ferro M, Gaskell S, Hagan I, Stapley B, et al. 2002. A nuclear pro- tein in Schizosaccharomyces pombe with homology to the human tumour suppressor Fhit has decapping activity. Mol Microbiol 46: 49-62.

Shen EC, Stage-Zimmermann T, Chui P, Silver PA. 2000. The yeast mRNA-binding protein Npl3p interacts with the cap-binding complex. J Biol Chem 275: 23718-23724.

Shen V, Liu H, Liu SW, Jiao X, Kiledjian M. 2008. DcpS scavenger decapping enzyme can modulate pre-mRNA splicing. RNA 14: 1132-1142.

Singh J, Salcius M, Liu SW, Staker BL, Mishra R, Thurmond J, Michaud G, Mattoon DR, Printen J, Christensen J, et al. 2008. DcpS as a therapeutic target for spinal muscular atrophy. ACS Chem Biol 3: 711-722.

Sonenberg N, Rupprecht KM, Hecht SM, Shatkin AJ. 1979. Eukaryotic mRNA cap binding protein: purification by affinity chromatography on sepharose-coupled $\mathrm{m}^{7} \mathrm{GDP}$. Proc Natl Acad Sci 76: 4345-4349.

Stepinski J, Waddell C, Stolarski R, Darzynkiewicz E, Rhoads RE. 2001. Synthesis and properties of mRNAs containing the novel "anti-reverse" cap analogs 7-methyl(3'-O-methyl)GpppG and 7-methyl (3'-deoxy)GpppG. RNA 7: 1486-1495.

Szczepaniak SA, Jemielity J, Zuberek J, Kufel J, Darzynkiewicz E. 2008. Bisphosphonate mRNA cap analog attached to Sepharose for affinity chromatography of decapping enzymes. Nucleic Acids Symp Ser (Oxf) 52: 295-296.

Topisirovic I, Svitkin YV, Sonenberg N, Shatkin AJ. 2011. Cap and cap-binding proteins in the control of gene expression. Wiley Interdisciplinary Reviews: RNA 2: 277-298.

Trowbridge DB, Yamamoto DM, Kenyon GL. 1972. Ring openings of trimetaphosphoric acid and its bismethylene analog. Syntheses of adenosine $5^{\prime}$-bis(dihydroxyphosphinylmethyl) phosphinate and 5'-amino-5'-deoxyadenosine 5'-triphosphate. J Am Chem Soc 94: $3816-3824$.

Vasiljeva L, Buratowski S. 2006. Nrd1 interacts with the nuclear exosome for 3' processing of RNA polymerase II transcripts. Mol Cell 21: 239-248.

von der Haar T, Gross JD, Wagner G, McCarthy JE. 2004. The mRNA cap-binding protein eIF4E in post-transcriptional gene expression. Nat Struct Mol Biol 11: 503-511.

Webb NR, Chari RV, DePillis G, Kozarich JW, Rhoads RE. 1984. Purification of the messenger RNA cap-binding protein using a new affinity medium. Biochemistry 23: 177-181.

Wong CM, Qiu H, Hu C, Dong J, Hinnebusch AG. 2007. Yeast cap binding complex impedes recruitment of cleavage factor IA to weak termination sites. Mol Cell Biol 27: 6520-6531.

Yoshikawa M, Kato T, Takenishi T. 1967. A novel method for phosphorylation of nucleosides to $5^{\prime}$-nucleotides. Tetrahedron Lett 50: 5065-5068.

Zapata JM, Martinez MA, Sierra JM. 1994. Purification and characterization of eukaryotic polypeptide chain initiation factor 4F from Drosophila melanogaster embryos. J Biol Chem 269: 18047-18052.

Zuberek J, Wyslouch-Cieszynska A, Niedzwiecka A, Dadlez M, Stepinski J, Augustyniak W, Gingras AC, Zhang Z, Burley SK, Sonenberg N, et al. 2003. Phosphorylation of eIF4E attenuates its interaction with mRNA $5^{\prime}$ cap analogs by electrostatic repulsion: Intein-mediated protein ligation strategy to obtain phosphorylated protein. RNA 9: 52-61.

Zuberek J, Jemielity J, Jablonowska A, Stepinski J, Dadlez M, Stolarski R, Darzynkiewicz E. 2004. Influence of electric charge variation at residues 209 and 159 on the interaction of eIF4E with the mRNA 5' terminus. Biochemistry 43: 5370-5379. 

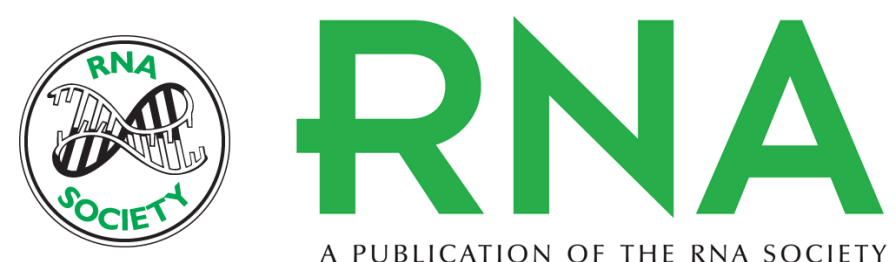

A PUBLICATION OF THE RNA SOCIETY

\section{Affinity resins containing enzymatically resistant mRNA cap analogs -a new tool for the analysis of cap-binding proteins}

Sylwia Anna Szczepaniak, Joanna Zuberek, Edward Darzynkiewicz, et al.

RNA 2012 18: 1421-1432 originally published online May 15, 2012

Access the most recent version at doi:10.1261/rna.032078.111

Supplemental http://rnajournal.cshlp.org/content/suppl/2012/04/26/rna.032078.111.DC1
Material

References This article cites 65 articles, 25 of which can be accessed free at: http://rnajournal.cshlp.org/content/18/7/1421.full.html\#ref-list-1

License

Email Alerting Receive free email alerts when new articles cite this article - sign up in the box at the Service top right corner of the article or click here.

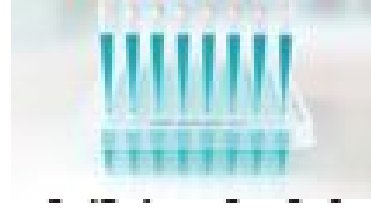

Providing Precise Solutions for your research.

To subscribe to RNA go to:

http://rnajournal.cshlp.org/subscriptions 